\title{
Wind-wave modelling aspects within complicate topography
}

\author{
S. Christopoulos \\ Division of Hydraulics and Environmental Engineering, Department of Civil Engineering, Aristotle University of Thessaloniki, 54006
} Thessaloniki, Greece

Received: 4 September 1995 / Revised: 23 July 1996 / Accepted: 6 August 1996

\begin{abstract}
Wave forecasting aspects for basins with complicate geomorphology, such as the Aegean Sea, are investigated through an intercomparison study. The efficiency of the available wind models (ECMWF, UKMO) to reproduce wind patterns over special basins, as well as three wave models incorporating different physics and characteristics (WAM, AUT, WACCAS), are tested for selected storm cases representing the typical wind situations over the basin. From the wave results, discussed in terms of time-series and statistical parameters, the crucial role is pointed out of the wind resolution and the reliability of the different wave models to estimate the wave climate in such a basin. The necessary grid resolution is also tested, while for a specific test case (December 1991) ERS-1 satellite data are compared with those of the model.
\end{abstract}

\section{Introduction}

Wave forecasting is very important for many activities, such as navigation, maritime tourism, seafarming, offshore and coastal works and marine system management. A lot of scientific effort during the last decades has been devoted to developing powerful and enhanced wave models in order to predict the wave climate in the oceans and the larger seas, e.g. global (Clancy et al., 1986; WAMDI Group, 1988), North Sea (Burgers, 1990) and Mediterranean Sea (Cavaleri et al., 1991).

An interesting application of the wave forecasting models is implementation on smaller basins with special geomorphological characteristics such as the Baltic Sea, the Aegean Sea and so on. A representative example of these basins is the Aegean Sea, a special sub-basin of the Mediterranean Sea with a very complicated topography and coastline where hundreds of islands are scattered all over the basin. The wave assessment in the Aegean Sea is very important for safe navigation (commercial, maritime tourism) and good service in the transporta- tion of the tourists all over the Greek Islands. Nevertheless, very few studies have been implemented for the wave climate in Aegean Sea. Recently, a few research studies have been integrated in the field of wave modelling (Kassimidis, 1986; Christopoulos, 1989; Christopoulos and Koutitas, 1991), and the field of long-term wave statistics (Athanassoulis and Skarsoulis, 1992). The measured data are very few, concerning short periods of measurement for the demands of local coastal projects, and there is no systematic recording of waves for short-term analysis (Cavaleri et al., 1993).

Focusing on such a special basin, there is an attempt to investigate major and minor aspects of a wave forecasting system. The various available wave models should be tested to check the incorporated physics and the qualitative and quantative results. The existing wind data is also a crucial factor for the credibility of the wave forecast results. Finally, the grid resolution will affect the simulation of the real basin and the necessary CPU time.

In order to face these aspects of wave modelling we have distinguished three categories of test:

a Wind input. The efficiency of the available wind information from various sources to resolve the orography effect is checked.

$b$ Wave models. The performance of the various wave models for this characteristic basin is highlighted by implementing the models using the same wind input.

$c$ Grid resolution. The choice of the best grid resolution for describing the special features of the basin, such as the complicated coastline and the numerous islands, is investigated.

Within this context, we begin with the description of the basin with its geographical characteristics and the discussion of the main wind systems (Sect. 2). In Sect. 3 the available wave models and wind data are briefly presented. A number of wave-model runs is established by identifying representative storm cases and making all the possible combinations of implementations, which characterise the test categories just given. The details of the wave-model runs are given in Sect. 4. The results, 
either as time-series of the wave parameters or as calculated statistical values, are discussed in Sect. 5. The wave results are compared with ERS-1 satellite data for a specific test case in order to verify and check some features revealed in previous sections (Sect. 6). Finally the findings from this wind-wave modelling intercomparison study are summarised in the last section.

\section{The Aegean Sea}

The Aegean Sea is situated to the north-east of the Ionian and to the north-west of the Levantine Seas (Fig. 1). It is bounded to the east by the Turkish coast, to the north and west by the Greek mainland and to the south by Crete. Its coastline is very irregular, and hundreds of smaller and larger islands are scattered all over the Aegean. Another special feature is the existence of large mountains around the basin, pointing out the significance of the orography effect for this basin, small in size (Fig. 2). Its area is approximately $2 \times 10^{5} \mathrm{~km}^{2}$, which is about one tenth of the area of the Mediterranean.

Three major basins exist (Laskaratos, 1992). In the north, the Mount Athos depression extends in a WSW to ENE direction, from the Sporades islands in the west to the south of eastern limits of North Greece, with maximum depths of up to $1500 \mathrm{~m}$. The Chios basin in the Central Aegean, west of Chios and north-west of Samos, with depths of up to $1100 \mathrm{~m}$, is bounded in the south by the Cyclades, and communicates with the

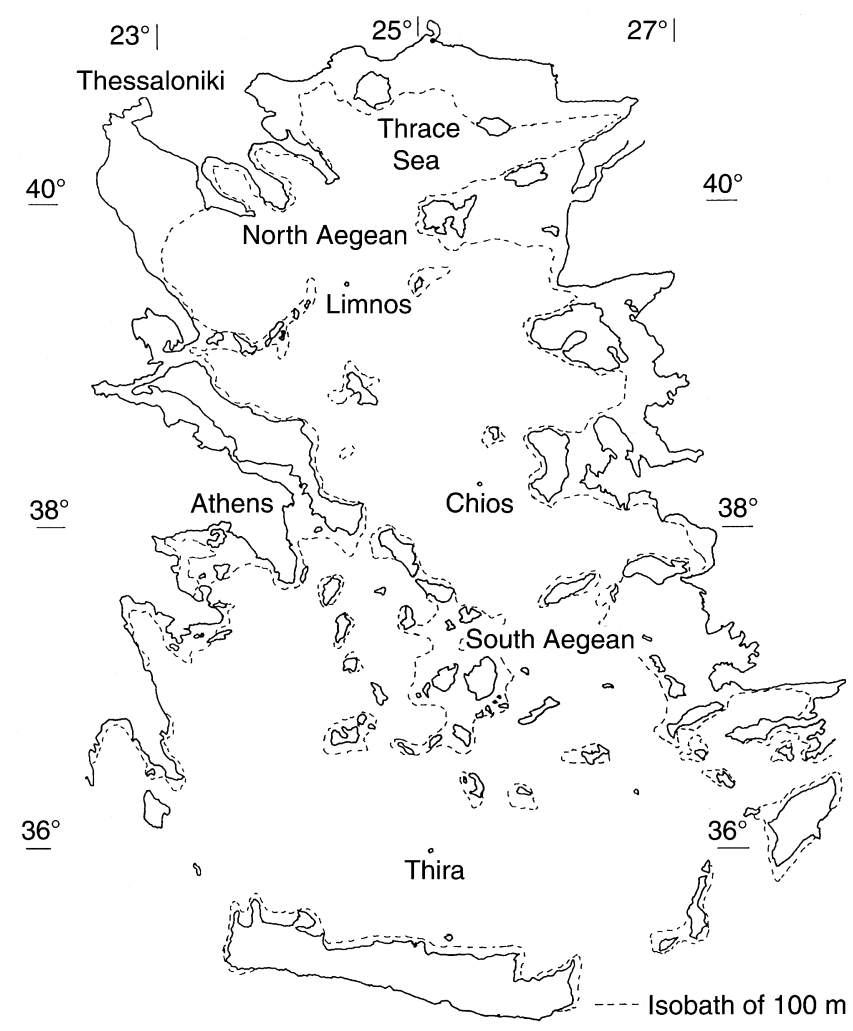

Fig. 1. Aegean Sea

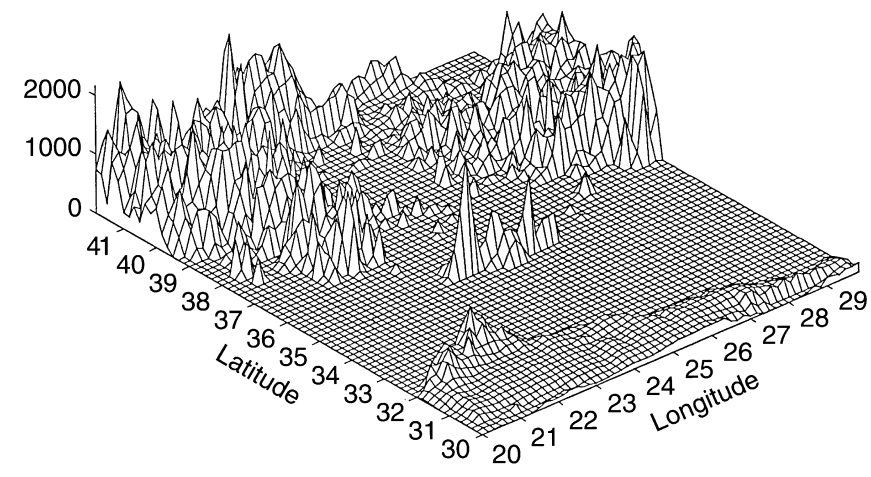

Fig. 2. Aegean basin orography

Mount Athos basin through a 400-m-deep sill. The third basin, the depression north of Cretan coasts, is by far the largest and deepest. It extends east to west and has maximum depths of $2500 \mathrm{~m}$. The Aegean joins the Mediterranean through several passages, the passage between Rhodes and Turkey and the Carpathos Strait to the south-east, the Caso Strait to the south, and the Kithira passages to the south-west. The Aegean is connected to the Black Sea through the Sea of Marmara.

Thus for geomorphological reasons and from the point of view of wave climate interest in the Aegean Sea, three sub-parts can be distinguished, the North Aegean extending from the parallel of $39.5^{\circ} \mathrm{N}$ till the coastline of Macedonia and Thrace, the Central Aegean extending from the parallel of about $38^{\circ} \mathrm{N}$ till $39.5^{\circ}$ and the South Aegean with the Cretan sea, extending from about $38^{\circ} \mathrm{N}$ to the north coasts of Crete.

The most frequent winds that prevail in the Aegean during the four seasons are the winds of the northern sector. Less frequent are the winds of the southern sector, while the western and eastern winds have much lower frequencies. This is due not only to the dynamics of the basin but also to the physicogeographical factors of the Aegean (Catsoulis, 1970).

In summer, dry winds of the northern sector, called Etesians and reaching sometimes gale force, prevail. The dynamic factors involved in the generation of the Etesian are:

- the high-pressure system of the Azores which in summer moves north and extends to south-eastern Europe and the Balkans;

- the deep asiatic low which extends to the west and sometimes further than Cyprus;

- the western Russia high;

- the high-pressure fields of north-western Europe which often reach the Aegean.

The most important factors are the first two. Each one of these two fields, separately, can generate Etesian winds, but the long series of consecutive Etesian days are created by an additive effect of both pressure fields (Carapiperis, 1968). The maximum wind force starts from the northern Aegean, passes slightly east of Limnos and Skyros, through the Cyclades, past 
Table 1. North-south wind distribution in July and January in the Aegean Sea

\begin{tabular}{|c|c|c|c|}
\hline $\begin{array}{l}\text { Location of } \\
\text { HMS Stations }\end{array}$ & $\begin{array}{l}\text { July } \\
\text { (NW-N-NE) }\end{array}$ & $\begin{array}{l}\text { January } \\
(\mathrm{NW}-\mathrm{N}-\mathrm{NE})\end{array}$ & $\begin{array}{l}\text { January } \\
\text { (SW-S-SE) }\end{array}$ \\
\hline \multicolumn{4}{|c|}{ Limnos $\left(39^{\circ} 53,25^{\circ} 04\right)$} \\
\hline $1-2 \mathrm{BF}$ & 12 & 10 & 6 \\
\hline $3-5 \mathrm{BF}$ & 47 & 23 & 16 \\
\hline $6-7 \mathrm{BF}$ & 10 & 13 & 6 \\
\hline \multirow[t]{2}{*}{$>7 \mathrm{BF}$} & 1 & 2 & 1 \\
\hline & $70 \%$ & $48 \%$ & $29 \%$ \\
\hline \multicolumn{4}{|c|}{ Skiros $\left(38^{\circ} 54,24^{\circ} 33\right)$} \\
\hline $1-2 \mathrm{BF}$ & 14 & 6 & 11 \\
\hline $3-5 \mathrm{BF}$ & 56 & 23 & 16 \\
\hline $6-7 \mathrm{BF}$ & 7 & 16 & 7 \\
\hline \multirow[t]{2}{*}{$>7 \mathrm{BF}$} & 3 & 1 & 1 \\
\hline & $77 \%$ & $48 \%$ & $34 \%$ \\
\hline \multicolumn{4}{|c|}{ Mikonos $\left(37^{\circ} 28,25^{\circ} 20\right)$} \\
\hline $1-2 \mathrm{BF}$ & 11 & 8 & 8 \\
\hline $3-5 \mathrm{BF}$ & 52 & 28 & 16 \\
\hline $6-7 \mathrm{BF}$ & 22 & 16 & 2 \\
\hline \multirow{2}{*}{$>7 \mathrm{BF}$} & & 2 & \\
\hline & $85 \%$ & $54 \%$ & $26 \%$ \\
\hline
\end{tabular}

Karpathos island and moves on towards the centre of the eastern Levantine.

In winter, the Aegean is the site of violent wind storms on both the northern and southern sectors. Typical wind patterns are shown in Fig. 3, while in Table 1 results from the statistical analysis of wind data for a 20-year period (1950-1968), reveal the mentioned characteristics of the winds over Aegean sea. The wind data have been measured from the stations network of Hellenic Meteorological Service (HMS).

\section{Available information}

\subsection{Wind data}

Information on wind speed and direction can be provided by the meteorological models run operationally by various meteorological services. For the area of Aegean Sea the wind fields produced by the European Centre for Medium-Range Weather Forecasts and the U.K. Meteorological Office (hence referred to as ECMWF and UKMO, respectively) are in principle available for hindcasting and forecasting purposes. For the hindcast test cases presented here, the analysed winds at $10 \mathrm{~m}$ above sea level are used

3.1.1 ECMWF Winds. ECMWF produces routine global analyses for the four main synoptic hours $00,06,12$ and 18 UTC and global 10-day forecasts based on 12-UTC data. Until September 1991, ECMWF was running the T106 components spectral meteorological model with a three-dimensional spatial representation. The vertical

Fig. 3a-c. Wind patterns in Aegean Sea. a North winds, winter; b north winds, summer; c south winds
Aegean Sea, - $10 \mathrm{~m}$ wind at 20 January 1991, 00:00 UT

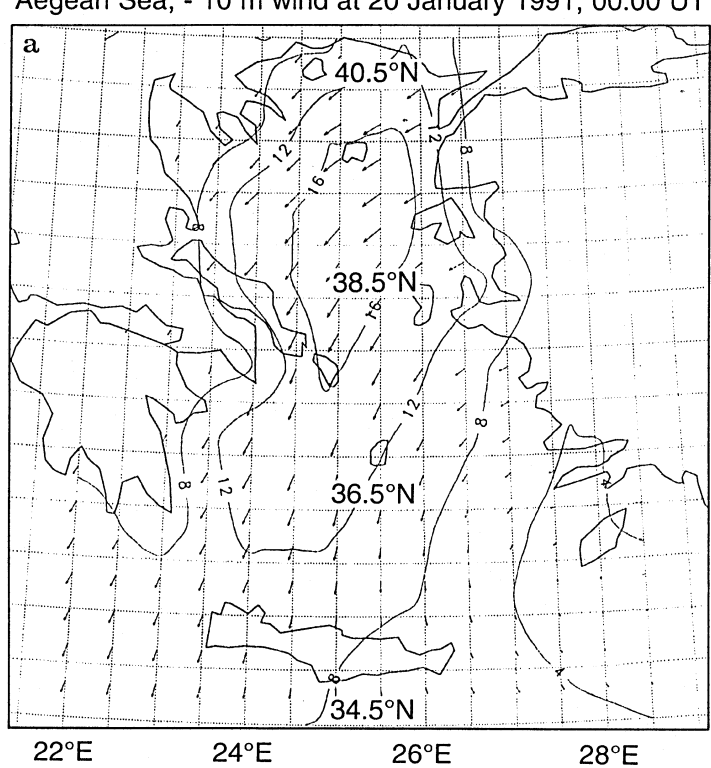

Aegean Sea, $-10 \mathrm{~m}$ wind at 25 August 1990, 06:00 UT

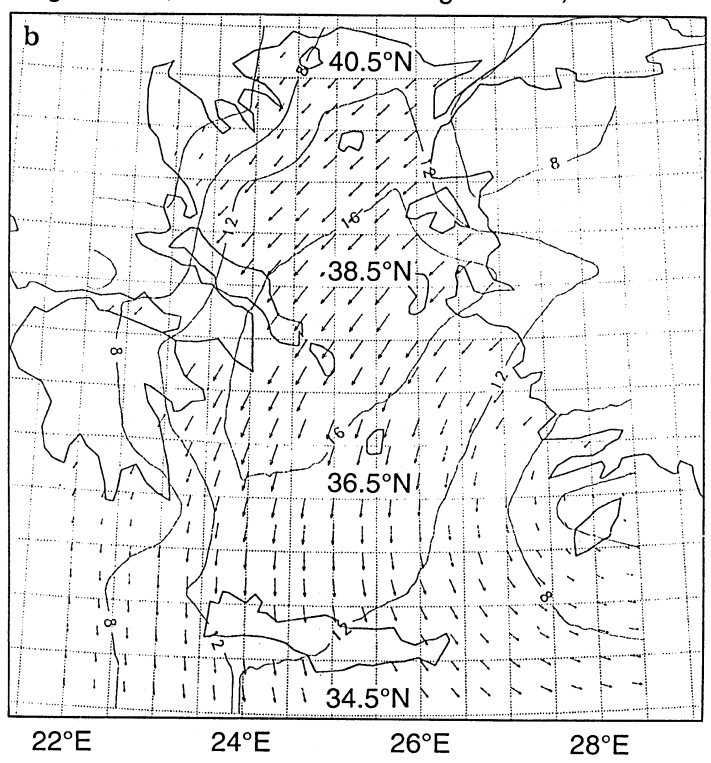

Aegean Sea, - $10 \mathrm{~m}$ wind at 28 February 1990, 06:00 UT

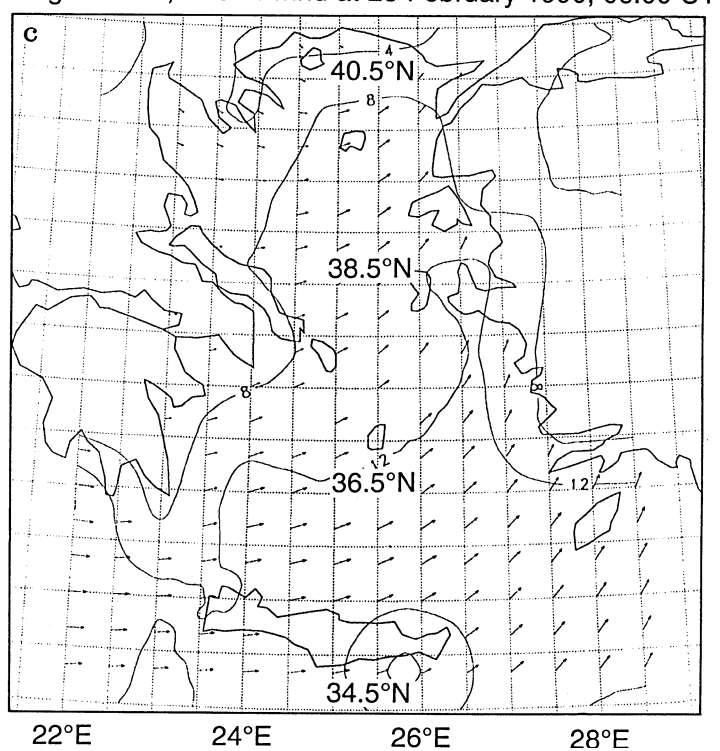


resolution is 19 layers, while horizontally the model uses two different numerical prescriptions: the spectral prescription (106 wave numbers) representing upper air fields, and the computation of their gradients and the grid-point prescription (resolution of $1.125^{\circ}$ ) used for computing adiabatic terms and the non-adiabatic, physical parametrisation.

In September 1991 ECMWF made operational a new high-resolution version of its forecast model the T213 (Simmons, 1991). A target resolution of T213 in the horizontal and 31 levels in the vertical (T213/L31) was set, entailing a doubling of horizontal resolution (about $80 \mathrm{~km}$ for the Aegean Sea latitudes), and an approximate doubling of vertical resolution between the boundary layer and stratospheric model levels. The doubling of vertical resolution is crucial for improving the description of orography, while the doubling of horizontal resolution is better for the description of the small basins with complicated geometry, like the Aegean Sea.

\subsubsection{UKMO Winds. Until September 1991 UKMO ran} a global model, plus a European limited-area model (LAM) including the Mediterranean Sea, the latter with a resolution of $0.9375^{\circ}$ in longitude and $0.75^{\circ}$ in latitude, both corresponding to about $80 \mathrm{~km}$ at $40^{\circ}$ latitude.

Then in September 1991, UKMO started running routinely the unified forecast climate model (Cullen, 1991), essentially doubling its grid resolution. The unified model code is designed to allow any distribution of levels, with most common the use of the standard 20level configuration, while for the upper-atmospheric modelling the 42-level configuration is used, extended up to $0.25 \mathrm{hpa}$. A regular latitude-longitude grid is used in the horizontal with $\Delta \phi=0.833^{\circ}$ in latitude and $\Delta \lambda=1.25^{\circ}$ in longitude.

The LAM uses spherical polar coordinates, where the coordinate pole is not placed at the geographical pole but at $30^{\circ} \mathrm{N}, 160^{\circ} \mathrm{E}$, in order to obtain uniform resolution over the area of interest. The resolution is $0.442^{\circ}$ in each direction, resulting in $40-\mathrm{km}$ resolution for the Aegean Sea.

\subsection{Wave models}

Various wave models having different physics, hence characterised as first-, second- and third-generation wave models, were tested for the scope of this study. The special features of each model are highlighted in the following paragraphs.

3.2.1 WACCAS. A computer code based on model WACCAS (wave-climate categorisation by storms) has been organised and generalised in order to calculate time-series of significant wave height $H_{s}$ and peak period $T_{z}$. This model can be characterised as enhanced empirical method (Burrows et al., 1988), and uses the integrated JONSWAP relations for the contributing fetches to estimate the wave parameters provided that the topography of the basin and the wind field are given.

3.2.2 AUT. The AUT model (Christopoulos and Koutitas, 1991) is a second-generation wave model simulating the wave-energy balance equation for deep water on a grid:

$\frac{\partial F}{\partial t}+C_{g} \cos \theta \frac{\partial F}{\partial x}+C_{g} \sin \theta \frac{\partial F}{\partial y}=S_{i n}+S_{n l}+S_{d s}$.

A simple numerical scheme is used for the advection, while the source terms are estimated with the most recent mathematical expressions. For the wind input the Bight of Abaco formula is used (Snyder et al., 1981):

$S_{\text {in }}=\beta F(f, \theta)$,

$\beta=0.14 \frac{\rho_{\alpha}}{\rho_{\omega}}\left[\frac{U_{10} \cos \left(\theta-\theta_{\omega}\right)}{C}-1\right] 2 \pi f$,

where $\rho_{\alpha}$ is the air density, $\rho_{\omega}$ is the water density, $C$ is the phase speed of waves, $U_{10}$ is the wind speed at $10 \mathrm{~m}$ above the sea surface and $\theta_{\omega}$ is the wind direction. The wave dissipation is estimated on the basis of Hasselmann's theory (Komen et al., 1984)

$S_{d s}=-1.6 \omega^{2} \hat{\alpha}^{2} \frac{F}{\bar{\omega}}$

where $\bar{\omega}$ is the mean angular frequency and $\hat{\alpha}$ is an integral wave steepness parameter.

The non-linear energy transfer is treated implicitly by adapting the wind-sea spectrum to a prescribed spectrum, such as that of JONSWAP (Hasselmann et al., 1973). Special focus is given to conserve the wave energy after its redistribution, by using prognostic relations and analytical expressions for the estimation of peak frequency $f_{p}$, the Phillips parameter $\alpha$ and the peak enhancement factor $\gamma$.

3.2.3 WAM. The third-generation wave model (The WAMDI Group, 1988) integrates the basic transport equation describing the evolution of a two-dimensional ocean wave spectrum without additional ad hoc assumptions regarding the spectral shape. The windinput source function is adopted from Snyder et al. (1981), while the dissipation source function is based on the formula proposed by Komen et al. (1984). Both functions are calculated through Eqs. 3 and 4 as in the AUT case. The main difference compared with the AUT model is that the non-linear source function is estimated by the discrete interaction operator parametrisation proposed by Hasselmann and Hasselmann (1985).

In the cycle- 3 version of the model, the code was reorganised and new features such as the refraction by bottom topography and currents, as well as the nesting, were incorporated. In the current version of WAM, 
cycle 4 , the main goal is the inclusion of the new physics proposed by Janssen (1989) concerning the coupling between wind and waves and the sea-state dependent wind input.

\section{Organisation of the runs}

\subsection{Selected cases}

The selected storms are representative examples of typical meteorological situations. Criteria such as frequency, the intensity of the associated winds, the spatial extension and the duration of the storm were considered for the selection of the test cases.

The chosen cases represent mainly wind events from northerly winds during summer (Etesian) and winter which occurred within the last five years. The chosen cases are shown chronologically: 1) February-March 1990; 2) August 1990; 3) September-October 1990; 4) December 1990; 5) January 1991; 6) December 1991.

The Etesian winds are represented by the cases 2 and 3 , where north to north-easterly winds start blowing in upper part of the Aegean Sea, passing to its southern parts, and then moving through the Carpathos strait to the basin of the eastern Mediterranean. Case 2 is more intense (wind peaks over $16 \mathrm{~ms}^{-1}$ ) than case 3 (wind peaks $\left.12-16 \mathrm{~ms}^{-1}\right)$.

The winter northerly winds are represented by case 5 . $\mathrm{NE}$ winds were blowing in the northern part with maximum wind values in the range $20-24 \mathrm{~ms}^{-1}$ (16 January 1991), passing from the central part and moving north-eastwards towards the eastern Mediterranean. A special characteristic of this case is the persistence of strong winds $\left(12-16 \mathrm{~ms}^{-1}\right.$ and higher) for about nine days (15-23 January).

The case of south winds in winter is represented by case 4. South-easterly winds from Carpathos straits and southwesterly winds from Kithira straits enter in the South Aegean Sea, passing as south winds through the central region and prevailing as south-westerly in the northern part. Peak wind values are in the range of $16-20 \mathrm{~ms}^{-1}$.

In cases 1 and 6 storm events with both south and north winds exist. In case 1 two peaks occur, one on 23 February, maximum wind values $12-16 \mathrm{~ms}^{-1}$, and the other on 28 February, with peak wind values in the range $16-20 \mathrm{~ms}^{-1}$ from north-westerly winds covering the whole basin. In between, south winds developed entering from the Kithira Strait (maximum values 27 February). In case 6 the southern-wind event developed greatly on 21 December (peak wind values $12-16 \mathrm{~ms}^{-1}$ ), while the northern-wind event occurred on 26 December (maximum wind values in the range 20-24 ms ${ }^{-1}$ ). Case 6 covers the applicability of the new wind products from both ECMWF and UKMO services.

\subsection{Tests to carry out}

Aiming to cover completely all the test categories concerning the comparison of the wind input using the same wind, the comparison of the wave models using the same wind, as well as the implementation of the models with different grid resolutions, all possible combinations between available wind and wave models for the selected cases have been made. According to the focusing point the situation is as follows:

Wind input: The available wind information comes from the meteorological models of ECMWF and UKMO. In particular, for the test case of December 1991 the new ECMWF model, the new global (UKMOGLO) and limited-are a (UKMO-LAM) versions of the UKMO are used. Additionally, for one case (August 1990), wind measurements from the station network of the HMS are used, with wind values from ten stations located mainly in the South Aegean.

Wave models: The used wave models for the Aegean Sea are mainly the second-generation wave model AUT and the third-generation wave model WAM, plus the confined use of the enhanced empirical model WACCAS. For case 6 (December 1991), both versions, cycle 3 and cycle 4, of the WAM model have been implemented.

Grid: Two different grids have been considered, with $1 / 12^{\circ}$ (3583 gridpoints) and $1 / 6^{\circ}$ (894 gridpoints) resolutions, taking into account the conflicting factors of the correct representation of the basin and the economy in computing time.

The 26 runs concerning the six test cases appear analytically in Table 2 .

\subsection{Output points}

Because of the lack of measured data, the intercomparison study in the Aegean Sea is focused on certain characteristic gridpoints representing the wave evolution in the three sub-basins. The selected output points can be seen in Fig. 1 and have the following geographical coordinates: Limnos (North Aegean) $39.5^{\circ} \mathrm{N}, 24.5^{\circ} \mathrm{E}$, Chios (Central Aegean) $38.33^{\circ} \mathrm{N}, 25.5^{\circ} \mathrm{E}$, Thira (South Aegean) $36^{\circ} \mathrm{N}, 25^{\circ} \mathrm{E}$.

\subsection{Implementation of the models}

The wave models are implemented on the Aegean sea grid, which is extended from $22^{\circ} \mathrm{E}$ to $28.5^{\circ} \mathrm{E}$ and from $34.5^{\circ} \mathrm{N}$ to $41^{\circ} \mathrm{E}$. The WAM model uses the directional spectrum with 25 frequencies in geometric progression $\left(f_{1}=0.05 \mathrm{~Hz}, f_{n+1}=1.1 \times f_{1}\right)$ and 12 directional bands with $30^{\circ}$ resolution. In the AUT model the discretised spectrum consists of 24 frequencies $\left(f_{1}=0.04 \mathrm{~Hz}, f_{n+1}=1.14 \times f_{1}\right)$ and 12 directional bands also with $30^{\circ}$ resolution.

\section{Analysis of the results}

The results of the wave runs are compared in terms of specific wave parameters, such as the significant wave height $H_{s}$, the mean period $T_{z}$ and the mean wave direction $\theta_{m}$, calculated at the three representative grid 
Table 2. The 26 implemented runs for the intercomparison study in Aegean Sea

\begin{tabular}{|c|c|c|c|c|}
\hline No. & Date & Model & Wind & Grid \\
\hline 1 & $\begin{array}{l}\text { February } 1990 \\
(23 / 2-5 / 3)\end{array}$ & $\begin{array}{l}\text { WAM-CY3 } \\
\text { WAM-CY3 } \\
\text { AUT } \\
\text { WACCAS }\end{array}$ & $\begin{array}{l}\text { UKMO } \\
\text { ECMWF } \\
\text { UKMO } \\
\text { UKMO }\end{array}$ & $\begin{array}{l}1 / 6 \\
1 / 6 \\
1 / 6 \\
1 / 6\end{array}$ \\
\hline 2 & $\begin{array}{l}\text { August } 1990 \\
(23-28 / 8)\end{array}$ & $\begin{array}{l}\text { WAM-CY3 } \\
\text { WAM-CY3 } \\
\text { WAMCY-3 } \\
\text { AUT } \\
\text { AUT } \\
\text { WACCAS } \\
\text { AUT } \\
\text { AUT }\end{array}$ & $\begin{array}{l}\text { UKMO } \\
\text { UKMO } \\
\text { ECMWF } \\
\text { UKMO } \\
\text { UKMO } \\
\text { UKMO } \\
\text { ECMWF } \\
\text { HMS }\end{array}$ & $\begin{array}{l}1 / 6 \\
1 / 12 \\
1 / 6 \\
1 / 6 \\
1 / 12 \\
1 / 6 \\
1 / 6 \\
1 / 6\end{array}$ \\
\hline 3 & $\begin{array}{l}\text { September } 1990 \\
(27 / 9-3 / 10)\end{array}$ & $\begin{array}{l}\text { WAM-CY3 } \\
\text { WAM-CY3 }\end{array}$ & $\begin{array}{l}\text { UKMO } \\
\text { ECMWF }\end{array}$ & $\begin{array}{l}1 / 6 \\
1 / 6\end{array}$ \\
\hline 4 & $\begin{array}{l}\text { December } 1990 \\
(10-16 / 12)\end{array}$ & $\begin{array}{l}\text { WAM-CY3 } \\
\text { WAM-CY3 }\end{array}$ & $\begin{array}{l}\text { UKMO } \\
\text { ECMWF }\end{array}$ & $\begin{array}{l}1 / 6 \\
1 / 6\end{array}$ \\
\hline 5 & $\begin{array}{l}\text { January } 1991 \\
(14-31 / 1)\end{array}$ & $\begin{array}{l}\text { WAM-CY3 } \\
\text { WAM-CY3 } \\
\text { AUT }\end{array}$ & $\begin{array}{l}\text { UKMO } \\
\text { ECMWF } \\
\text { UKMO }\end{array}$ & $\begin{array}{l}1 / 6 \\
1 / 6 \\
1 / 6\end{array}$ \\
\hline 6 & $\begin{array}{l}\text { December } 1991 \\
(15-31 / 12)\end{array}$ & $\begin{array}{l}\text { WAM-CY3 } \\
\text { WAM-CY3 } \\
\text { WAM-CY3 } \\
\text { WAM-CY4 } \\
\text { WAM-CY4 } \\
\text { WAM-CY4 } \\
\text { AUT }\end{array}$ & $\begin{array}{l}\text { UKMO GLO (new) } \\
\text { UKMO LAM (new) } \\
\text { ECMWF (new) } \\
\text { UKMO GLO (new) } \\
\text { UKMO LAM (new) } \\
\text { ECMWF (new) } \\
\text { UKMO LAM (new) }\end{array}$ & $\begin{array}{l}1 / 6 \\
1 / 6 \\
1 / 6 \\
1 / 6 \\
1 / 6 \\
1 / 6 \\
1 / 6\end{array}$ \\
\hline
\end{tabular}

points. The comparison is focused on the most important parameter, $H_{s}$, which reflects the intensity of the storm event and the amount of grown wave energy. Tables with statistics are provided to show the overall behaviour of the runs in terms of statistical parameters like the mean value, the bias and the normalised bias, the root mean square difference and the normalised rms difference or normalised scatter index. Definitions of the wave parameters and the statistical parameters are given in the Appendix.

\subsection{Comparison of wind inputs (19 runs - 6 test cases)}

This category concerns the main comparison between the UKMO and ECMWF wind products implemented with the WAM model for all the test cases. Additionally, there is a comparison between the AUT-wave-model implementations with the wind products UKMO, ECMWF and HMS, respectively.

In general, the UKMO winds produce higher wave heights than the ECMWF winds (Figs. 4 and 5). Although there is good agreement between the two time-series in most of the storm event, the difference comes from the peaks of the episodes, where the calculated values with UKMO winds are higher than the values with ECMWF winds, even sometimes of the order of two. This fact is more evident in North and
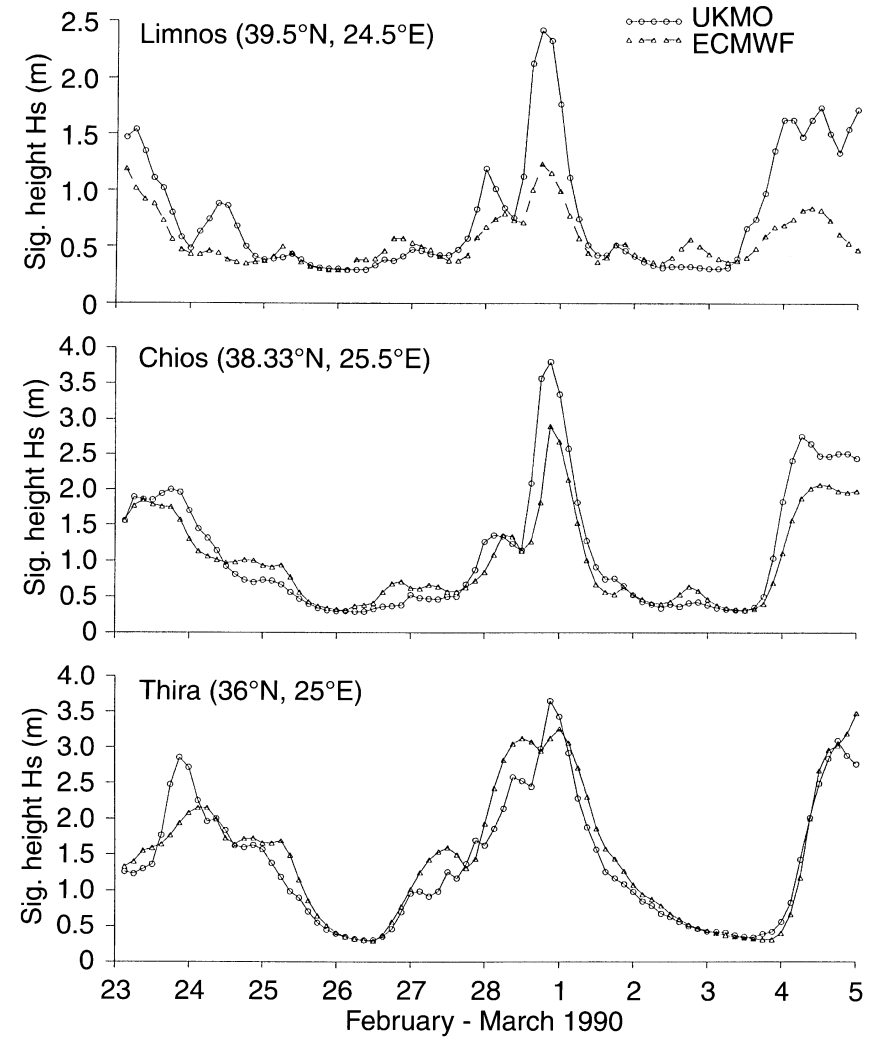

Fig. 4. Wave heights at specific grid points, February 1990 (UKMO v. ECMWF) 

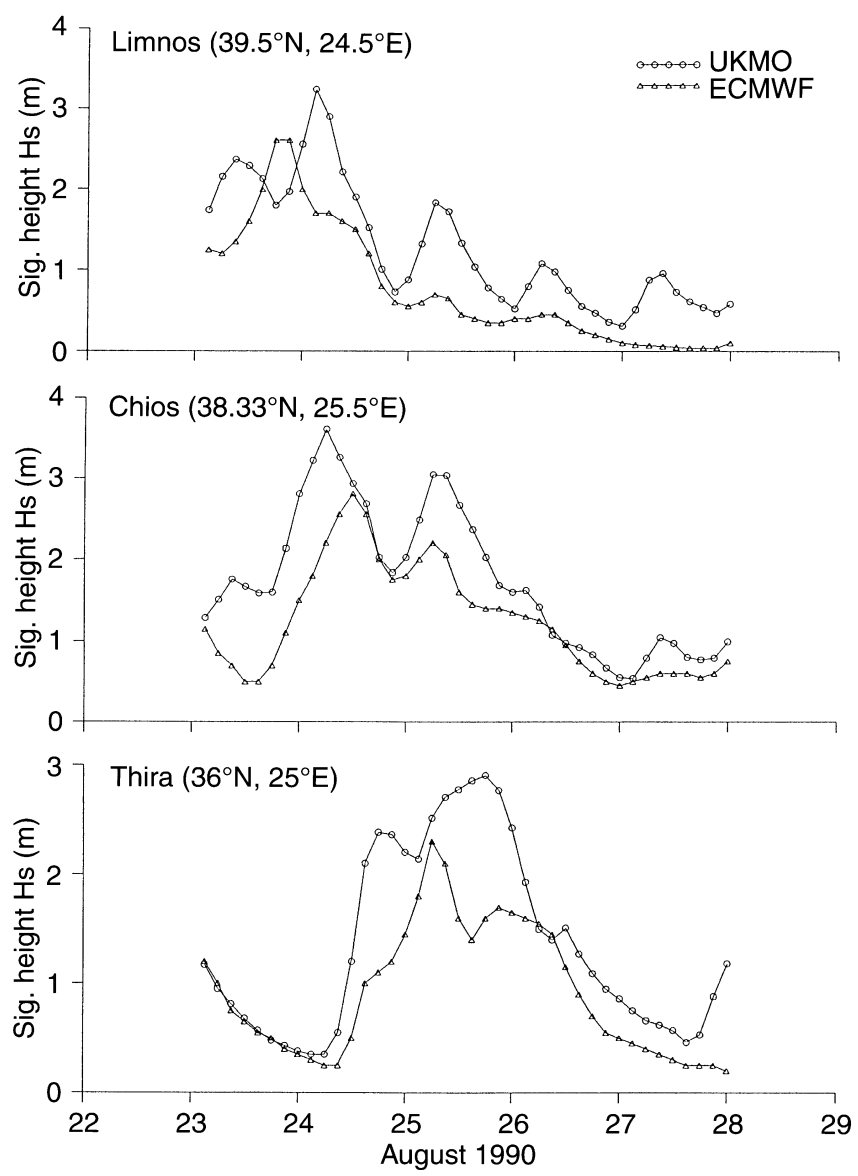

Fig. 5. Wave heights at specific grid points, August 1990 (UKMO v. ECMWF)

Central Aegean, where the effect of orography is crucial for the accurate representation of the wind fields.

The situation is similar for case 2 with the AUT model and the three wind-input sources (Fig. 6). The model results with HMS wind data are closer to the ECMWF results and lower than the UKMO results. This situation is also reflected in the wind evolution of the three sources at the three sub-basins (Fig. 7). At the Limnos gridpoint the UKMO wind is much higher, at least half through 25 August, when wind values are closer, thus reflecting the similar wave results. At the Chios gridpoint UKMO winds are still much higher (about 50\%), while ECMWF winds are close to HMS wind values. At the Thira gridpoint, due to enough neighbouring wind stations, the produced wind is more representative and there is better agreement between UKMO and HMS results.

In case 6, using the new wind products (UKMOGLO, UKMO-LAM, ECMWF) with finer resolutions, the overall picture is altered (Fig. 8). The difference between the wave results using UKMO-LAM wind and ECMWF wind correspondingly, is much smaller, of the order of 20-40 cm for the peak values (Tables 10,11). The UKMO-LAM values are higher in North and Central Aegean and the ECMWF higher in the South Aegean. These two models give higher values in
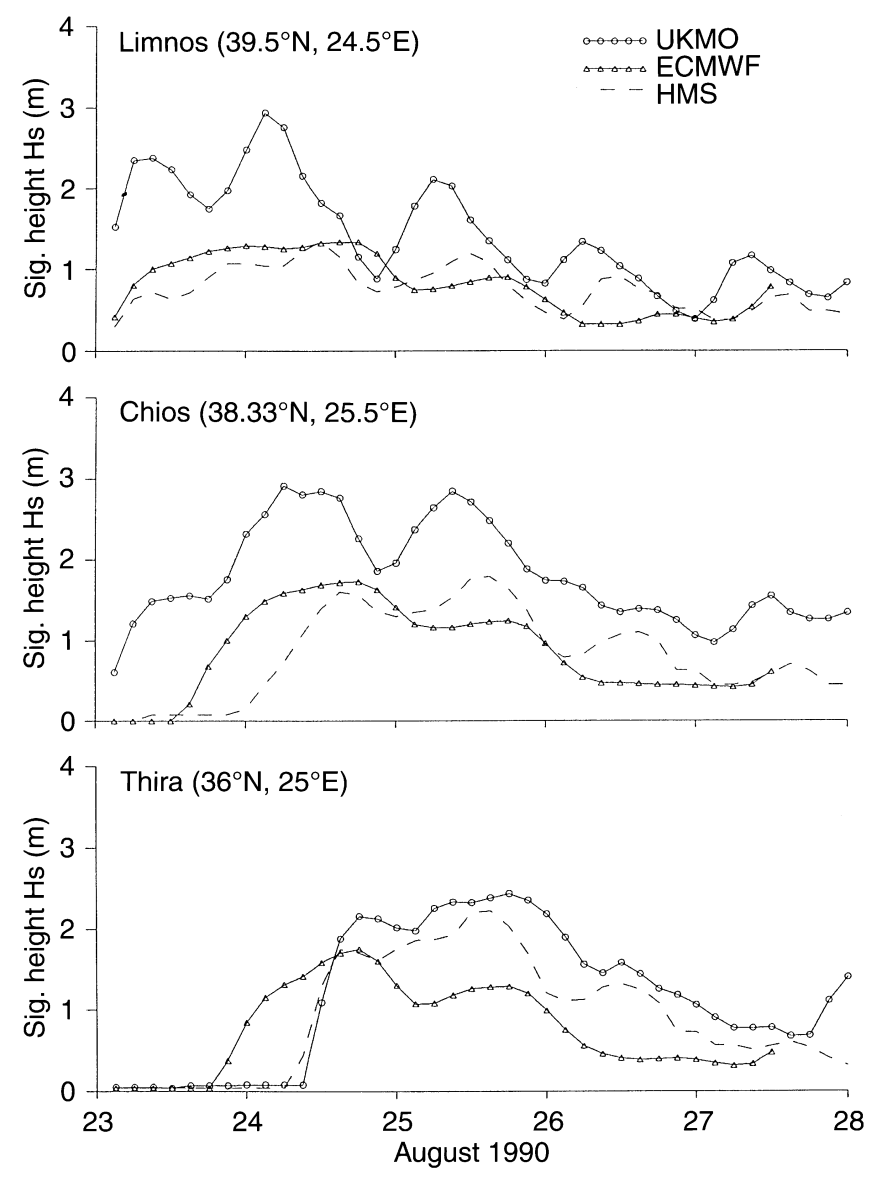

Fig. 6. Wave heights at specific grid points - AUT, August 1990 (UKMO v. ECMWF v. HMS)

comparison to the UKMO-GLO results. This is a fact that verifies the significant role of the wind-model resolution in wave-modelling results (finer resolution of UKMO-LAM and ECMWF compared with UKMOGLO). The orography effect, neighbouring mountains with heights over $2000 \mathrm{~m}$, is crucial for the analysis of the wind field. There is a need of a very fine resolution in the atmospheric model in order that the wind profile is simulated correctly. This has been discussed in detail by Luigi Cavaleri (Komen et al., 1994) especially for the Mediterranean Sea. The tests carried out for the Aegean Sea verify the strong impact of this factor for the wave hindcast and forecast purposes in such a complicated basin.

The characteristics of this category of comparison can be also revealed by the statistical results (Tables 311). Focusing on the parameter of bias, which gives the quantification of the difference for the overall time evolution of its test case, the situation is summarised in Fig. 9, showing the evolution of the bias through the test cases. In the North Aegean, bias is systematically negative, i.e. UKMO winds give higher waves, while the situation alters in the South Aegean, especially in test case 6, where ECMWF winds give higher waves. 

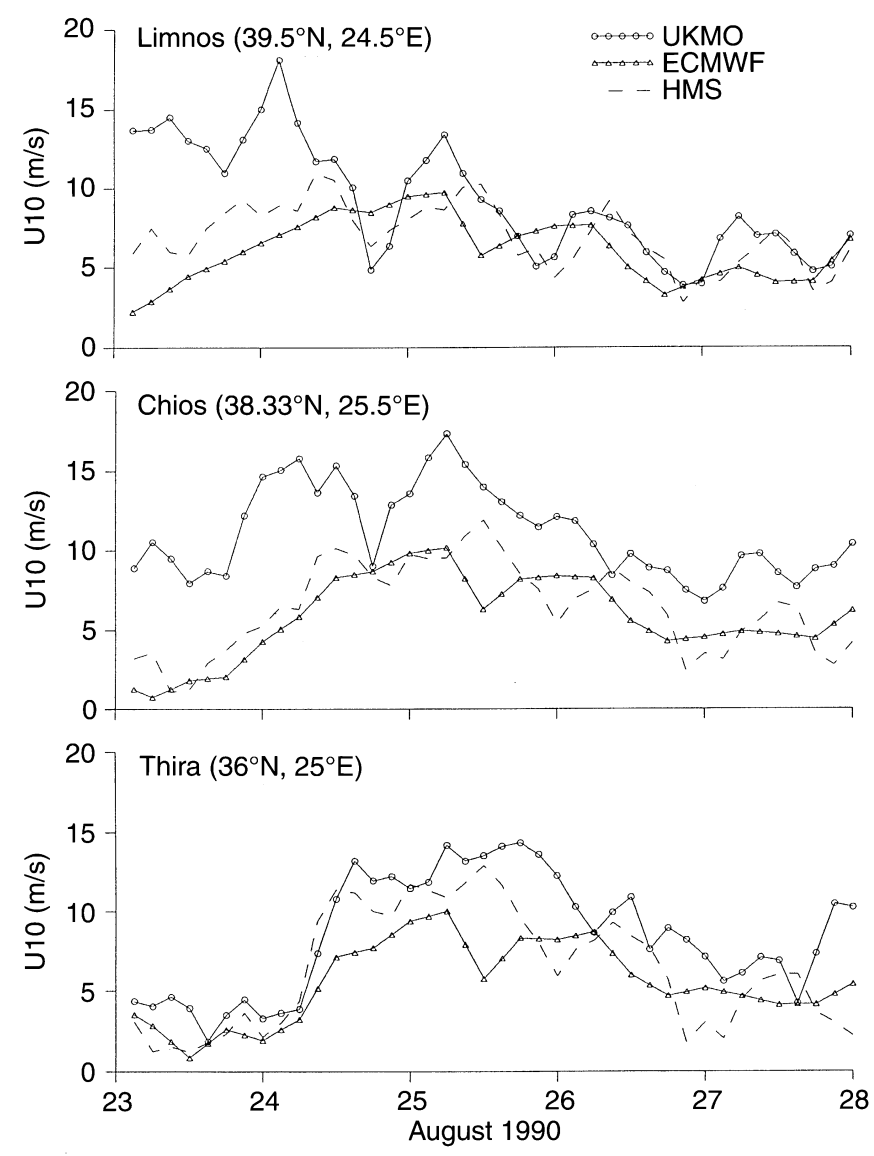

Fig. 7. Wind speed at specific grid points, August 1990 (UKMO v. ECMWF v. HMS)

\subsection{Comparison of wave models (17 runs -4 test cases $)$}

This category concerns mainly the comparison of the second-generation wave model AUT and the thirdgeneration wave model WAM implemented for the same wind input. For test cases 1 and 2, the results of the enhanced empirical model WACCAS are also presented. Main focus is given on testing models with different physics to various wind events. Two main wind situations can be recognised to highlight the differences of the models. In the first, the persistence of the wind blowing over the area is the main characteristic, in cases 2, 3 and 5, where north winds are blowing over the
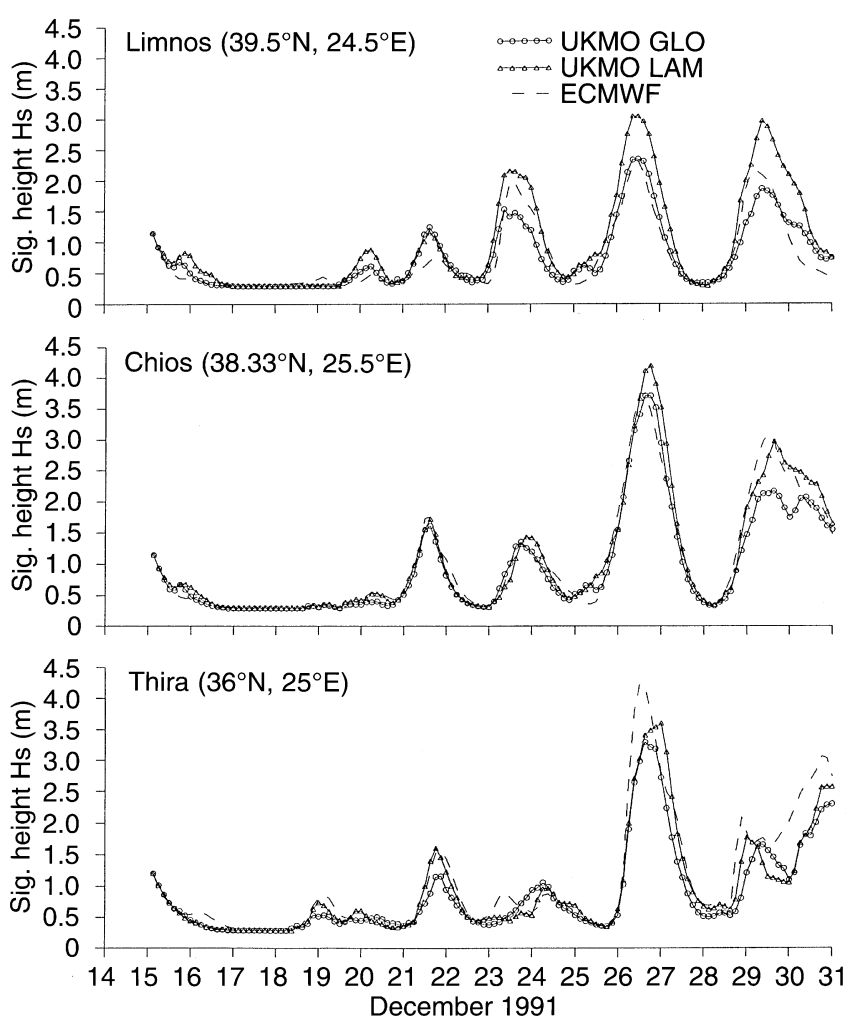

Fig. 8. Wave heights at specific grid points - WAM-cy3, December 1991 (UKMO GLO v. UKMO LAM v. ECMWF)

Aegean Sea for a long time; in the second situation the wind direction is alternated, as in cases 1 and 6 .

In the case of February 1990 the two models give similar results (Fig. 10). The same happens for the episode of August 1990. In these cases the disadvantages of the empirical model WACCAS are revealed for the Thira gridpoint, where the variability of winds in the broader region results in an undulatory evolution of wave height. In the case of January 1991 the agreement between the two models is very good (of the order of 10$20 \mathrm{~cm}$ ) throughout the whole episode. These features are presented also in Tables 12-14.

In the case of December 1991 the two versions of the WAM model, cycle 3 and cycle 4, and the AUT model, are compared (Fig. 11). In general, WAM cycle 4 compared with cycle 3 gives slightly higher values of significant wave height (of the order of $10 \mathrm{~cm}$ ) and much higher mean
Table 3. Statistics for the storm February 1990, -80 points. Comparison of results from WAM model using UKMO and ECMWF winds

\begin{tabular}{lccclll}
\hline & $\begin{array}{l}\text { Mean } \\
(1)\end{array}$ & $\begin{array}{c}\text { Mean } \\
(2)\end{array}$ & Bias & $\begin{array}{l}\text { Normalised } \\
\text { bias }\end{array}$ & $\begin{array}{l}\text { Root-mean- } \\
\text { square } \\
\text { difference }\end{array}$ & $\begin{array}{l}\text { Norm. rms } \\
\text { difference }\end{array}$ \\
\hline $\begin{array}{l}\text { Limnos } \\
H_{s}\end{array}$ & 0.78 & 0.55 & -0.23 & -0.13 & 0.43 & 0.34 \\
$T_{z}$ & 3.29 & 2.92 & -0.37 & -0.09 & 0.69 & 0.17 \\
Chios & & & & & & \\
$H_{s}$ & 1.12 & 0.99 & -0.13 & -0.03 & 0.37 & 0.28 \\
$T_{z}$ & 3.74 & 3.58 & -0.16 & -0.02 & 0.54 & 0.13 \\
Thira & & & & & & 0.20 \\
$H_{s}$ & 1.39 & 1.49 & 0.10 & 0.08 & 0.30 & 0.11 \\
$T_{z}$ & 4.31 & 4.52 & 0.21 & 0.05 & 0.43 & \\
\hline
\end{tabular}


Table 4. Statistics for the storm September 1990, -48 points. Comparison of results from WAM model using UKMO and ECMWF winds

\begin{tabular}{lllllll}
\hline & $\begin{array}{l}\text { Mean } \\
(1)\end{array}$ & $\begin{array}{l}\text { Mean } \\
(2)\end{array}$ & Bias & $\begin{array}{l}\text { Normalised } \\
\text { bias }\end{array}$ & $\begin{array}{l}\text { Root-mean- Norm. rms } \\
\text { square } \\
\text { difference }\end{array}$ & $\begin{array}{l}\text { difference } \\
\text { Limnos }\end{array}$ \\
$H_{s}$ & 0.71 & 0.37 & -0.34 & -0.50 & 0.58 & 0.59 \\
$T_{z}$ & 2.71 & 2.09 & -0.62 & -0.18 & 1.11 & 0.39 \\
Chios & & & & & & 0.39 \\
$H_{s}$ & 1.03 & 0.72 & -0.31 & -0.33 & 0.49 & 0.26 \\
$T_{z}$ & 3.46 & 3.12 & -0.34 & -0.04 & 0.68 & 0.32 \\
Thira & & & & & & 0.18 \\
$H_{s}$ & 0.94 & 0.8 & -0.14 & -0.15 & 0.28 & \\
$T_{z}$ & 3.57 & 3.23 & -0.34 & -0.11 & 0.54 & \\
\hline
\end{tabular}

Table 5. Statistics for the storm August 1990, -40 points. Comparison of results from WAM model using UKMO and ECMWF winds

\begin{tabular}{lllllll}
\hline & $\begin{array}{l}\text { Mean } \\
(1)\end{array}$ & $\begin{array}{l}\text { Mean } \\
(2)\end{array}$ & Bias & $\begin{array}{l}\text { Normalised } \\
\text { bias }\end{array}$ & $\begin{array}{l}\text { Root-mean- Norm. rms } \\
\text { square } \\
\text { difference }\end{array}$ & $\begin{array}{l}\text { difference } \\
\end{array}$ \\
& & & & & & \\
\hline Limnos & & & & & & \\
$H_{s}$ & 1.12 & 0.77 & -0.35 & -0.28 & 0.59 & 0.39 \\
$T_{z}$ & 3.35 & 2.71 & -0.64 & -0.18 & 0.89 & 0.23 \\
Chios & & & & & & \\
$H_{s}$ & 1.64 & 1.22 & -0.42 & -0.25 & 0.56 & 0.31 \\
$T_{z}$ & 4.42 & 3.98 & -0.44 & -0.09 & 0.64 & 0.14 \\
Thira & & & & & & \\
$H_{s}$ & 1.27 & 0.90 & -0.37 & -0.26 & 0.55 & 0.35 \\
$T_{z}$ & 4.20 & 3.63 & -0.57 & -0.14 & 0.79 & 0.20 \\
\hline
\end{tabular}

Table 6. Statistics for the storm December 1990, -48 points. Comparison of results from WAM model using UKMO and ECMWF winds

Mean Mean Bias Normalised Root-mean- Norm. rms

$\begin{array}{lllll}(1) & (2) & \text { bias } & \text { square } & \text { difference }\end{array}$

\begin{tabular}{lllllll}
\hline Limnos & & & & & & \\
$H_{s}$ & 0.88 & 0.58 & -0.30 & -0.31 & 0.44 & 0.44 \\
$T_{z}$ & 3.79 & 3.40 & -0.39 & -0.09 & 0.79 & 0.20 \\
Chios & & & & & & \\
$H_{s}$ & 1.18 & 0.90 & -0.28 & -0.13 & 0.60 & 0.48 \\
$T_{z}$ & 3.96 & 3.61 & -0.35 & -0.06 & 0.85 & 0.21 \\
Thira & & & & & & \\
$H_{s}$ & 1.20 & 1.13 & -0.07 & -0.01 & 0.57 & 0.46 \\
$T_{z}$ & 4.07 & 3.81 & -0.26 & -0.05 & 0.98 & 0.22 \\
\hline
\end{tabular}

Table 7. Statistics for the storm January 1991, -136 points. Comparison of results from WAM model using UKMO and ECMWF winds

\begin{tabular}{|c|c|c|c|c|c|c|}
\hline & $\begin{array}{l}\text { Mean } \\
\text { (1) }\end{array}$ & $\begin{array}{l}\text { Mean } \\
\text { (2) }\end{array}$ & Bias & $\begin{array}{l}\text { Normalised } \\
\text { bias }\end{array}$ & $\begin{array}{l}\text { Root-mean- } \\
\text { square } \\
\text { difference }\end{array}$ & $\begin{array}{l}\text { Norm. rms } \\
\text { difference }\end{array}$ \\
\hline \multicolumn{7}{|l|}{ Limnos } \\
\hline$H_{s}$ & 1.61 & 0.95 & -0.66 & -0.35 & 0.84 & 0.41 \\
\hline $\begin{array}{l}T_{z} \\
\text { Chios }\end{array}$ & 4.31 & 3.48 & -0.83 & -0.17 & 1.06 & 0.22 \\
\hline$H_{s}$ & 1.79 & 1.49 & -0.30 & -0.16 & 0.47 & 0.23 \\
\hline $\begin{array}{l}T_{z} \\
\text { Thira }\end{array}$ & 4.66 & 4.29 & -0.37 & -0.08 & 0.56 & 0.12 \\
\hline$H_{s}$ & 1.25 & 1.42 & 0.17 & 0.14 & 0.43 & 0.40 \\
\hline$T_{z}$ & 4.15 & 4.40 & 0.25 & 0.07 & 0.59 & 0.16 \\
\hline
\end{tabular}

Table 8. Statistics for the storm December 1991, -128 points. Comparison of results from WAM-cy3 model using UKMO GLO and ECMWF winds

\begin{tabular}{|c|c|c|c|c|c|c|}
\hline & $\begin{array}{l}\text { Mean } \\
\text { (1) }\end{array}$ & $\begin{array}{l}\text { Mean } \\
(2)\end{array}$ & Bias & $\begin{array}{l}\text { Normalised } \\
\text { bias }\end{array}$ & $\begin{array}{l}\text { Root-mean- } \\
\text { square } \\
\text { difference }\end{array}$ & $\begin{array}{l}\text { Norm. rms } \\
\text { difference }\end{array}$ \\
\hline \multicolumn{7}{|l|}{ Limnos } \\
\hline$H_{s}$ & 0.76 & 0.74 & -0.02 & -0.02 & 0.22 & 0.25 \\
\hline$T_{z}$ & 3.40 & 3.48 & 0.08 & 0.03 & 0.42 & 0.14 \\
\hline Chios & & & & & & \\
\hline$H_{s}$ & 0.95 & 1.04 & 0.09 & 0.08 & 0.24 & 0.20 \\
\hline $\begin{array}{l}T_{z} \\
\text { Thira }\end{array}$ & 3.69 & 3.81 & 0.12 & 0.03 & 0.34 & 0.10 \\
\hline$H_{s}$ & 0.85 & 1.05 & 0.20 & 0.21 & 0.38 & 0.38 \\
\hline$T_{z}$ & 3.58 & 3.98 & 0.40 & 0.11 & 0.64 & 0.18 \\
\hline
\end{tabular}

Table 9. Statistics for the storm December 1991, -128 points. Comparison of results from WAM-cy4 model using UKMO GLO and ECMWF winds

\begin{tabular}{lllllll}
\hline & $\begin{array}{l}\text { Mean } \\
(1)\end{array}$ & $\begin{array}{l}\text { Mean } \\
\text { (2) }\end{array}$ & & Bias & $\begin{array}{l}\text { Normalised } \\
\text { bias }\end{array}$ & $\begin{array}{l}\text { Root-mean- } \\
\text { square } \\
\text { difference }\end{array}$ \\
& & & $\begin{array}{l}\text { Norm. rms } \\
\text { difference }\end{array}$ \\
\hline Limnos & & & & & & \\
$H_{s}$ & 0.88 & 0.83 & -0.05 & -0.02 & 0.25 & 0.32 \\
$T_{z}$ & 4.28 & 4.35 & 0.07 & 0.02 & 0.45 & 0.12 \\
Chios & & & & & & \\
$H_{s}$ & 1.07 & 1.14 & 0.07 & 0.06 & 0.22 & 0.20 \\
$T_{z}$ & 4.61 & 4.69 & 0.08 & 0.02 & 0.36 & 0.09 \\
Thira & & & & & & \\
$H_{s}$ & 0.96 & 1.12 & 0.16 & 0.15 & 0.35 & 0.35 \\
$T_{z}$ & 4.39 & 4.67 & 0.28 & 0.06 & 0.52 & 0.12 \\
\hline
\end{tabular}

Table 10. Statistics for the storm December 1991, -128 points. Comparison of results from WAM-cy3 model using UKMO LAM and ECMWF winds

Mean Mean Bias Normalised Root-mean- Norm. rms

$\begin{array}{llll}\text { (1) } & (2) & \text { bias } & \begin{array}{l}\text { square } \\ \text { difference }\end{array}\end{array}$

\begin{tabular}{lllllll}
\hline Limnos & & & & & & \\
$H_{s}$ & 0.99 & 0.74 & -0.25 & -0.18 & 0.39 & 0.29 \\
$T_{z}$ & 3.67 & 3.48 & -0.19 & -0.04 & 0.52 & 0.14 \\
Chios & & & & & & \\
$H_{S}$ & 1.07 & 1.03 & -0.04 & -0.02 & 0.21 & 0.15 \\
$T_{z}$ & 3.82 & 3.80 & -0.02 & -0.01 & 0.32 & 0.09 \\
Thira & & & & & & \\
$H_{s}$ & 0.93 & 1.06 & 0.13 & 0.12 & 0.33 & 0.28 \\
$T_{z}$ & 3.75 & 3.98 & 0.23 & 0.06 & 0.48 & 0.13 \\
\hline
\end{tabular}

Table 11. Statistics for the storm December 1991, -128 points. Comparison of results from WAM-cy4 model using UKMO LAM and ECMWF new winds

\begin{tabular}{|c|c|c|c|c|c|c|}
\hline & $\begin{array}{l}\text { Mean } \\
\text { (1) }\end{array}$ & $\begin{array}{l}\text { Mean } \\
\text { (2) }\end{array}$ & Bias & $\begin{array}{l}\text { Normalised } \\
\text { bias }\end{array}$ & $\begin{array}{l}\text { Root-mean- } \\
\text { square } \\
\text { difference }\end{array}$ & $\begin{array}{l}\text { Norm. rms } \\
\text { difference }\end{array}$ \\
\hline \multicolumn{7}{|l|}{ Limnos } \\
\hline$H_{s}$ & 1.09 & 0.83 & -0.26 & -0.16 & 0.40 & 0.33 \\
\hline $\begin{array}{l}T_{z} \\
\text { Chios }\end{array}$ & 4.54 & 4.35 & -0.19 & -0.03 & 0.53 & 0.12 \\
\hline$H_{s}$ & 1.18 & 1.14 & -0.04 & -0.02 & 0.21 & 0.16 \\
\hline $\begin{array}{l}T_{z} \\
\text { Thira }\end{array}$ & 4.73 & 4.68 & -0.05 & -0.01 & 0.33 & 0.07 \\
\hline$H_{s}$ & 1.02 & 1.12 & 0.10 & 0.10 & 0.30 & 0.28 \\
\hline$T_{z}$ & 4.50 & 4.68 & 0.18 & 0.04 & 0.40 & 0.09 \\
\hline
\end{tabular}



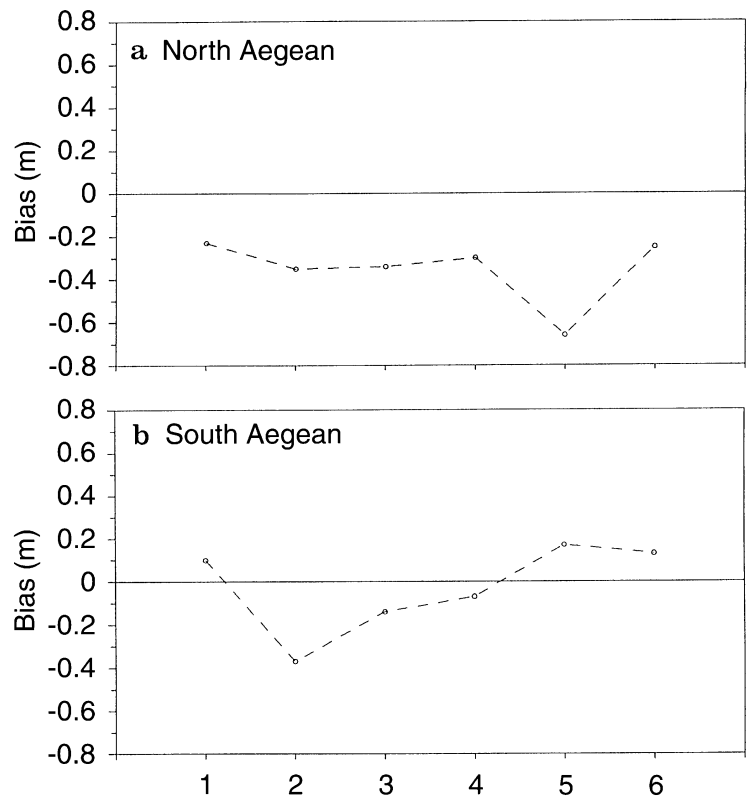

Fig. 9a,b. Bias of compared wave-height results with different wind source (UKMO v. ECMWF). a North Aegean; b South Aegean

periods (of the order of $1 \mathrm{~s}$ ), which is consistent with the new physics incorporated in cycle 4 and the treatment of the high-frequency region (Tables 15-17).

In general the two models' results are in good agreement. At some high peaks of wave energy, WAM
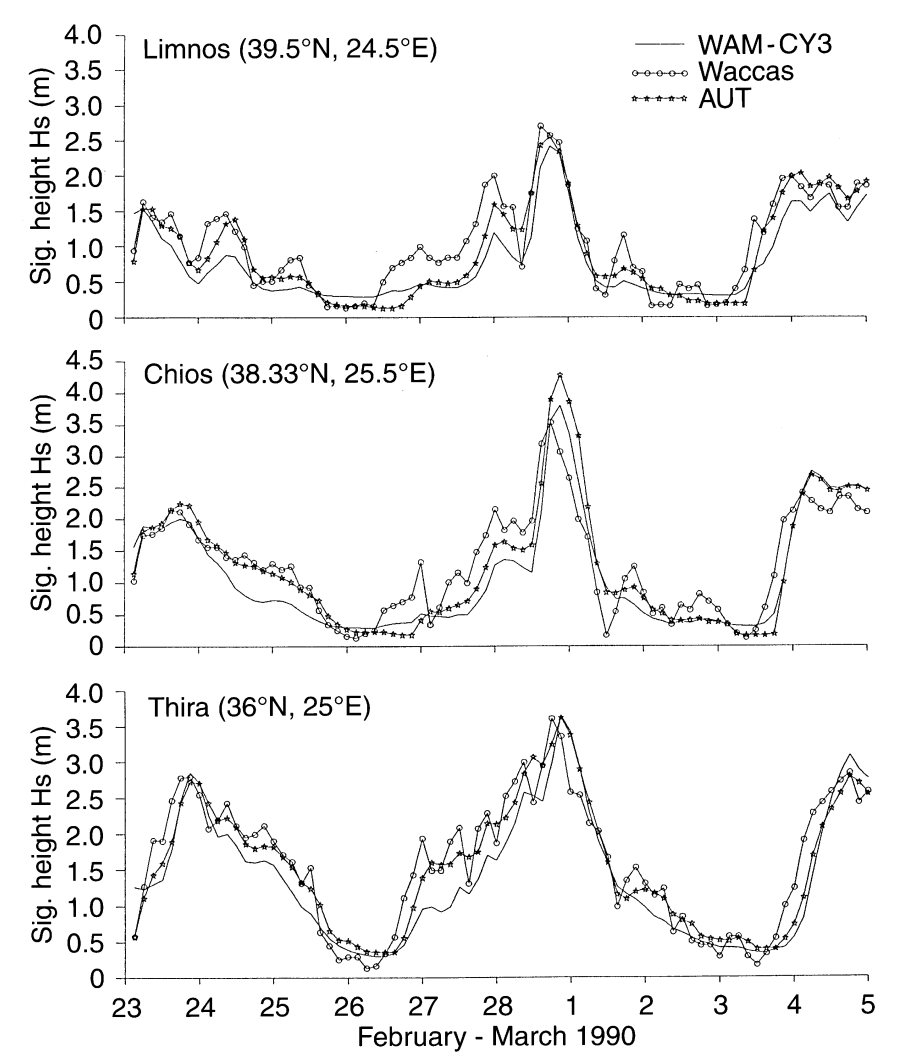

Fig. 10. Wave heights at specific grid points, February-March 1990 (WAM-cy3 v. AUT v. WACCAS)
Table 12. Statistics for the storm February-March 1990, -80 points. Comparison of results from WAM and AUT wave model using UKMO wind

\begin{tabular}{lllllll}
\hline & $\begin{array}{l}\text { Mean } \\
(1)\end{array}$ & $\begin{array}{l}\text { Mean } \\
(2)\end{array}$ & Bias & \multicolumn{2}{l}{$\begin{array}{l}\text { Normalised } \\
\text { bias }\end{array}$} & $\begin{array}{l}\text { Root-mean- Norm. rms } \\
\text { square } \\
\text { difference }\end{array}$ \\
& & & & \multicolumn{5}{l}{ difference } \\
\hline Limnos & & & & & & \\
$H_{s}$ & 0.55 & 0.91 & 0.36 & 0.55 & 0.62 & 1.01 \\
$T_{z}$ & 2.93 & 3.51 & 0.58 & 0.20 & 1.11 & 0.38 \\
Chios & & & & & & \\
$H_{s}$ & 1.00 & 1.25 & 0.25 & 0.15 & 0.50 & 0.42 \\
$T_{z}$ & 3.58 & 3.88 & 0.30 & 0.07 & 0.84 & 0.23 \\
Thira & & & & & & \\
$H_{s}$ & 1.48 & 1.54 & 0.06 & 0.11 & 0.30 & 0.25 \\
$T_{z}$ & 4.52 & 4.37 & -0.15 & -0.04 & 0.72 & 0.19 \\
\hline
\end{tabular}

Table 13. Statistics for the storm August 1990, -40 points. Comparison of results from WAM and AUT wave model using UKMO wind

Mean Mean Bias Normalised Root-mean- Norm. rms

$\begin{array}{llll}(1) & (2) & \text { bias } & \begin{array}{l}\text { square } \\ \text { difference }\end{array}\end{array}$

\begin{tabular}{lllllll}
\hline Limnos & & & & & & \\
$H_{s}$ & 1.12 & 1.42 & 0.30 & 1.91 & 0.45 & 3.74 \\
$T_{z}$ & 3.37 & 4.24 & 0.87 & 0.74 & 1.33 & 1.40 \\
Chios & & & & & & \\
$H_{s}$ & 1.74 & 1.81 & 0.07 & 0.17 & 0.38 & 0.38 \\
$T_{z}$ & 4.58 & 4.88 & 0.30 & 0.10 & 0.70 & 0.21 \\
Thira & & & & & & \\
$H_{s}$ & 1.35 & 1.17 & -0.18 & -0.20 & 0.38 & 0.48 \\
$T_{z}$ & 4.40 & 3.84 & -0.56 & -0.13 & 1.18 & 0.28 \\
\hline
\end{tabular}

Table 14. Statistics for the storm January 1991, -136 points. Comparison of results from WAM and AUT wave model using UKMO wind

\begin{tabular}{lllllll}
\hline & $\begin{array}{l}\text { Mean } \\
(1)\end{array}$ & $\begin{array}{l}\text { Mean } \\
(2)\end{array}$ & Bias & $\begin{array}{l}\text { Normalised } \\
\text { bias }\end{array}$ & $\begin{array}{l}\text { Root-mean- Norm. rms } \\
\text { square } \\
\text { difference }\end{array}$ & $\begin{array}{l}\text { difference } \\
\text { Limnos }\end{array}$ \\
& 1.61 & 1.75 & 0.14 & 0.12 & 0.29 & 0.33 \\
$H_{s}$ & 4.31 & 4.67 & 0.36 & 0.09 & 0.73 & 0.19 \\
$T_{z}$ & & & & & & \\
Chios & 1.79 & 1.70 & -0.09 & -0.02 & 0.37 & 0.30 \\
$H_{s}$ & 4.66 & 4.58 & -0.08 & -0.01 & 0.75 & 0.19 \\
$T_{z}$ & & & & & & \\
Thira & 1.25 & 1.39 & 0.14 & 0.15 & 0.30 & 0.39 \\
$H_{s}$ & 4.15 & 4.25 & 0.10 & 0.04 & 0.89 & 0.23 \\
$T_{z}$ & & & & & &
\end{tabular}

gives higher values, while at regions of low wave energy it seems that AUT retains some significant amount of energy, thus giving higher values. This is valid for both cases of persistent wind directions and alternate wind directions. It seems that in the case of August 1990, for the North Aegean, even the empirical model can give comparable results. In case 1, where the wind direction is alternated (north and south), the empirical models, due to their poor physics and the lack of spectral representation, cannot perform well, thus giving highlybiased values for the significant wave-height parameter. This is shown in Fig. 12, where the evolution of bias between the WAM and AUT models is more steady in 

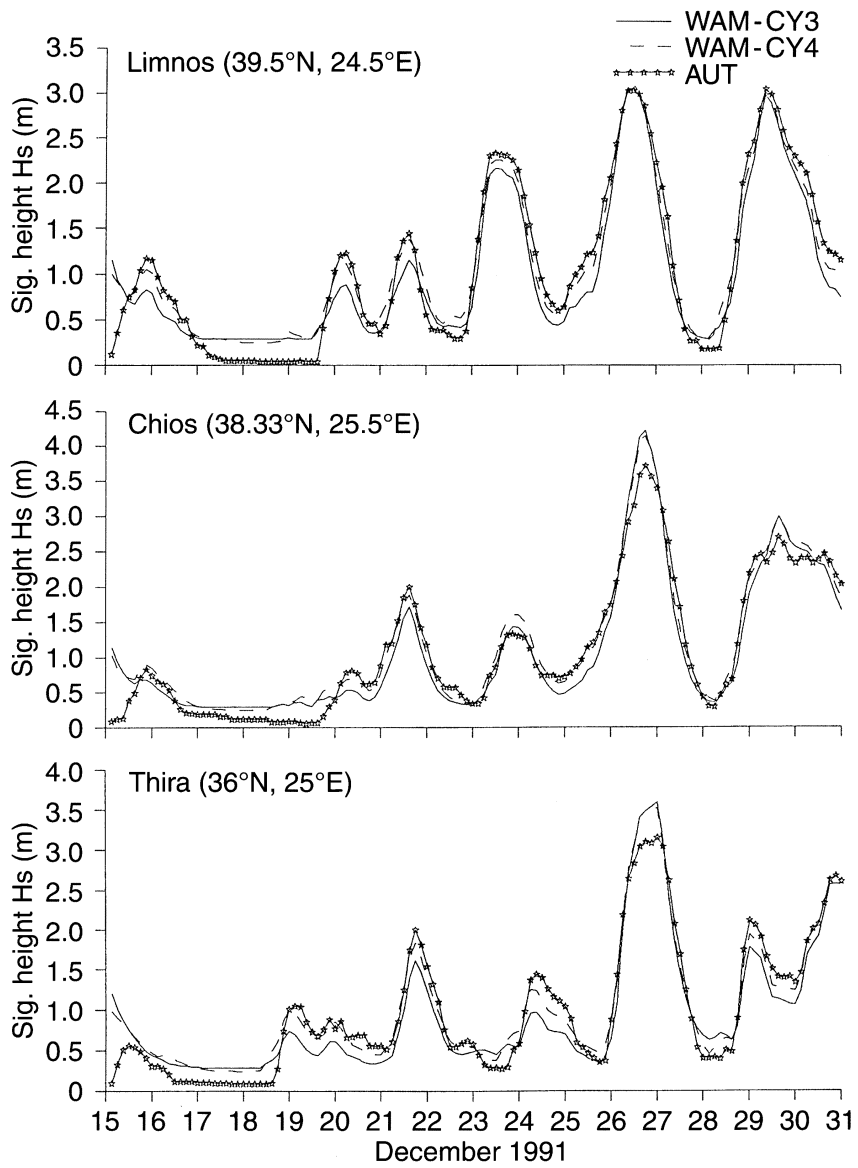

Fig. 11. Wave heights at specific grid points, December 1991 (WAMcy3 v. WAM-cy4 v. AUT)

cases of low wave energy events (case 1 - North Aegean), while in high-energy events the bias is very small (case 1 - South Aegean).

\subsection{Comparison of grid resolution ( 4 runs -1 test case)}

The grid resolution is examined for the case of August 1990 for both the AUT and WAM wave models. In both comparisons the wave results agree very well, with

Table 15. Statistics for the storm December 1991, -128 points. Comparison of results from WAM-cy3 and AUT model using UKMO LAM new wind

\begin{tabular}{lllllll}
\hline & $\begin{array}{l}\text { Mean } \\
(1)\end{array}$ & $\begin{array}{l}\text { Mean } \\
(2)\end{array}$ & Bias & $\begin{array}{l}\text { Normalised } \\
\text { bias }\end{array}$ & $\begin{array}{l}\text { Root-mean- Norm. rms } \\
\text { square } \\
\text { difference }\end{array}$ & $\begin{array}{l}\text { difference } \\
\text { Limnos }\end{array}$ \\
$H_{s}$ & 0.99 & 1.08 & 0.09 & -0.01 & 0.26 & 0.44 \\
$T_{z}$ & 3.67 & 3.68 & 0.01 & 0.00 & 0.85 & 0.24 \\
Chios & & & & & & \\
$H_{s}$ & 1.07 & 1.08 & 0.01 & -0.02 & 0.26 & 0.39 \\
$T_{z}$ & 3.82 & 3.78 & -0.04 & -0.01 & 0.70 & 0.20 \\
Thira & & & & & & \\
$H_{s}$ & 0.93 & 0.98 & 0.05 & 0.02 & 0.27 & 0.42 \\
$T_{z}$ & 3.75 & 3.58 & -0.17 & -0.04 & 0.84 & 0.22 \\
\hline
\end{tabular}

Table 16. Statistics for the storm December 1991, -128 points. Comparison of results from WAM model (cy3-cy4)using UKMO LAM new wind

\begin{tabular}{|c|c|c|c|c|c|c|}
\hline & $\begin{array}{l}\text { Mean } \\
(1)\end{array}$ & $\begin{array}{l}\text { Mean } \\
(2)\end{array}$ & Bias & $\begin{array}{l}\text { Normalised } \\
\text { bias }\end{array}$ & $\begin{array}{l}\text { Root-mean- } \\
\text { square } \\
\text { difference }\end{array}$ & $\begin{array}{l}\text { Norm.rms } \\
\text { difference }\end{array}$ \\
\hline \multicolumn{7}{|l|}{ Limnos } \\
\hline$H_{s}$ & 0.99 & 1.10 & 0.11 & 0.14 & 0.14 & 0.20 \\
\hline $\begin{array}{l}T_{z} \\
\text { Chios }\end{array}$ & 3.67 & 4.54 & 0.87 & 0.26 & 0.89 & 0.28 \\
\hline$H_{s}$ & 1.07 & 1.17 & 0.10 & 0.14 & 0.14 & 0.21 \\
\hline $\begin{array}{l}T_{z} \\
\text { Thira }\end{array}$ & 3.82 & 4.73 & 0.91 & 0.27 & 0.93 & 0.29 \\
\hline$H_{s}$ & 0.93 & 1.02 & 0.09 & 0.13 & 0.14 & 0.23 \\
\hline$T_{z}$ & 3.75 & 4.49 & 0.74 & 0.22 & 0.85 & 0.26 \\
\hline
\end{tabular}

Table 17. Statistics for the storm December 1991, -128 points. Comparison of results from WAM model (cy3-cy4) using ECMWF new wind

\begin{tabular}{lllllll}
\hline & $\begin{array}{l}\text { Mean } \\
(1)\end{array}$ & $\begin{array}{l}\text { Mean } \\
(2)\end{array}$ & Bias & $\begin{array}{l}\text { Normalised } \\
\text { bias }\end{array}$ & $\begin{array}{l}\text { Root-mean- Norm. } \\
\text { square } \\
\text { difference }\end{array}$ & $\begin{array}{l}\text { lms } \\
\text { difference }\end{array}$ \\
\hline $\begin{array}{l}\text { Limnos } \\
H_{s}\end{array}$ & 0.74 & 0.83 & 0.09 & -0.15 & 0.12 & 0.21 \\
$T_{z}$ & 3.48 & 4.35 & 0.87 & 0.27 & 0.90 & 0.29 \\
Chios & & & & & & \\
$H_{s}$ & 1.04 & 1.14 & 0.10 & 0.13 & 0.13 & 0.20 \\
$T_{z}$ & 3.80 & 4.68 & 0.88 & 0.25 & 0.90 & 0.27 \\
Thira & & & & & & \\
$H_{s}$ & 1.06 & 1.12 & 0.06 & 0.10 & 0.13 & 0.20 \\
$T_{z}$ & 3.98 & 4.68 & 0.70 & 0.20 & 0.83 & 0.25 \\
\hline
\end{tabular}
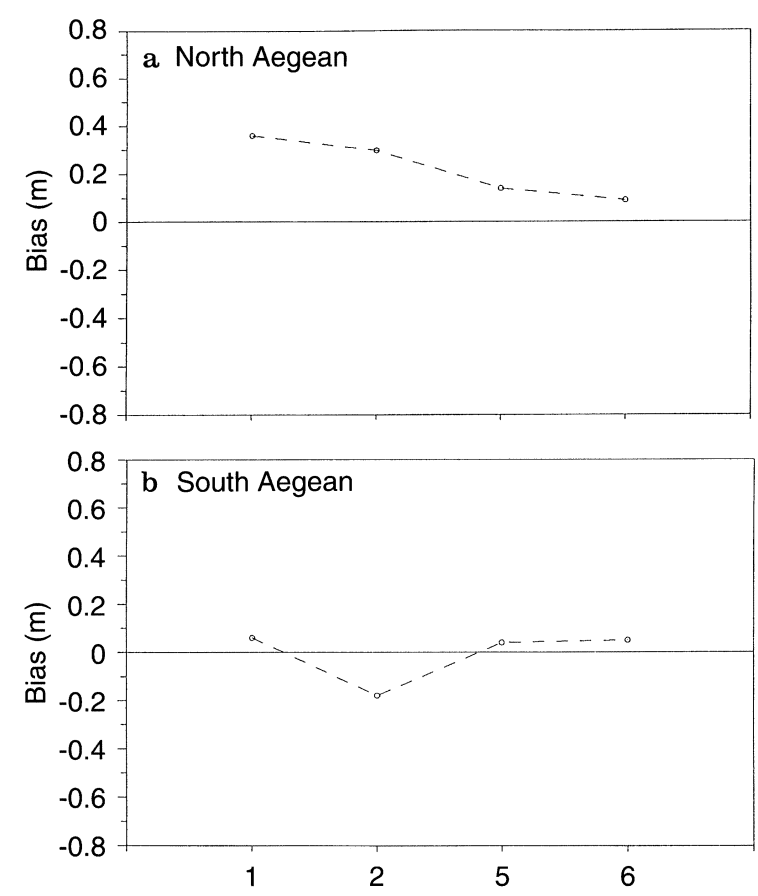

Fig. 12a,b. Bias of compared wave-height results with different wave models (WAM-cy3 v. AUT) a North Aegean; b South Aegean 

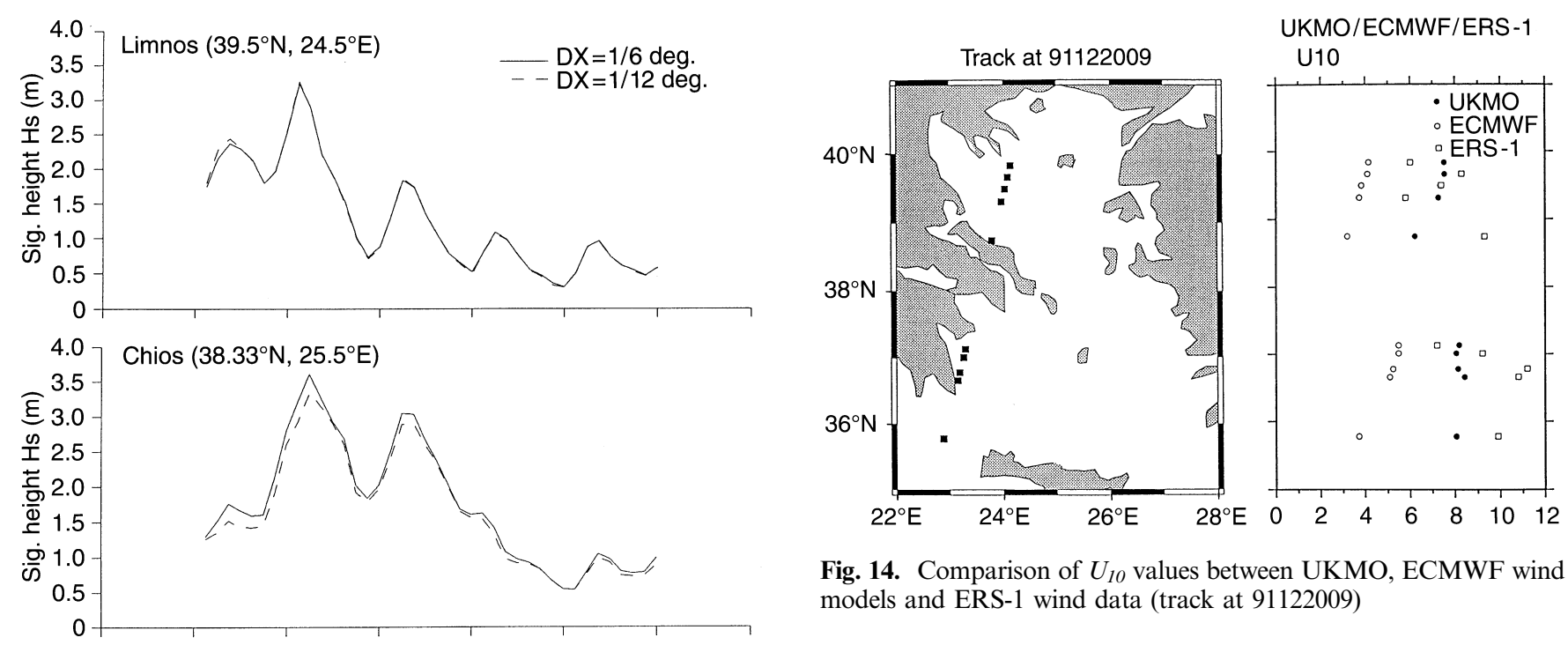

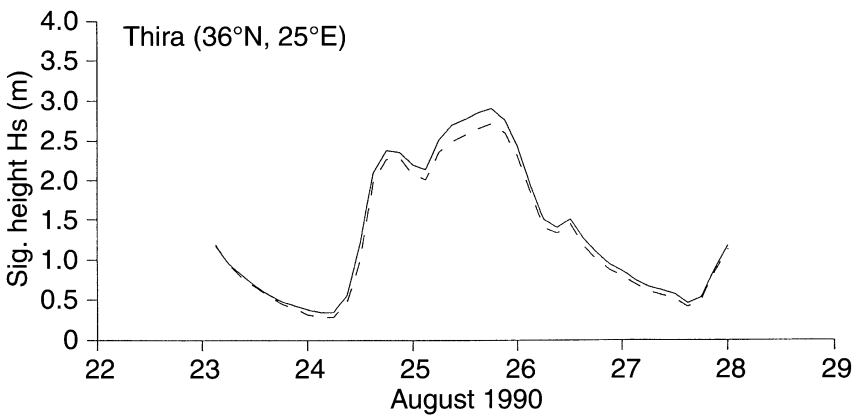

Fig. 13. Wave heights at specific grid points, August 1990 (grid $1 / 6^{\circ}$ v. grid $\left.1 / 12^{\circ}\right)$ WAM model

occasional small differences of up to $25 \mathrm{~cm}$. The larger differences appear at the Thira gridpoint representing the shadowing of Cyclades Islands just in front of it (Fig. 13).

\section{Comparison with satellite data}

The wave results for test case 6 are compared for two tracks of ERS-1 satellite passages over the Aegean Sea, the passage on 21 December at 0900 and five days later on 26 December at 0900 . The intercomparison study is again referred to the different wind input and to the different wave models used for the wave hindcast in the Aegean Sea.

The wind values given by the wind models UKMO and ECMWF are compared with the measured values from ERS-1 for both tracks. In the first track (Fig. 14), UKMO values are systematically greater than ECMWF values by an order of two, while ERS-1 values are greater than ECMWF values and comparable with UKMO ones through the track. In the second track (Fig. 15), the above characteristics of the three different wind sources are clearer. In the northern part of the track, it seems that the existence of the island of Thasos affects the satellite measurements, having as a result the ERS-1 values being close to the lower values of the ECMWF wind model. Also in the southern part of the track, it is
Fig. 14. Comparison of $U_{10}$ values between UKMO, ECMWF wind models and ERS-1 wind data (track at 91122009)

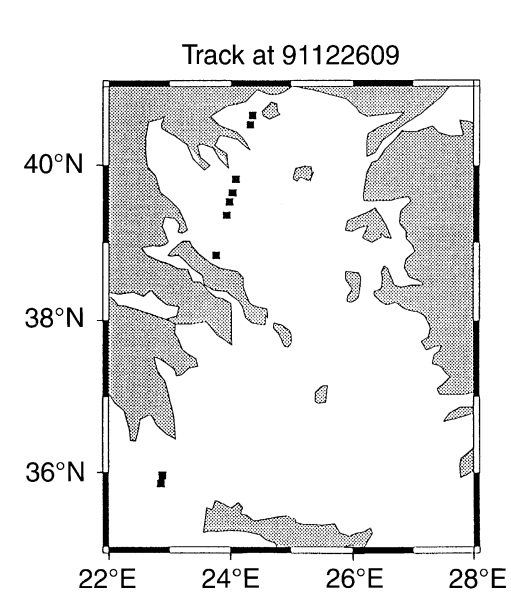

UKMO/ECMWF/ERS-1 U10

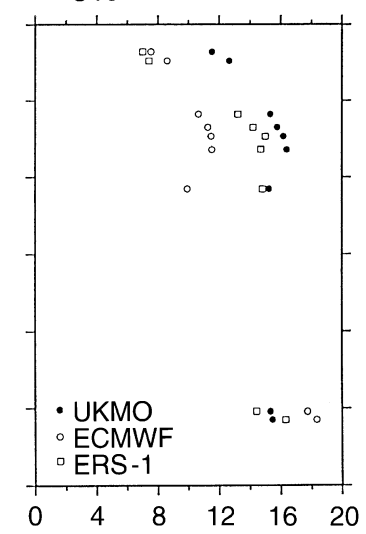

Fig. 15. Comparison of $U_{10}$ values between UKMO, ECMWF wind models and ERS-1 wind data (track at 91122609)

noticed that all three sets have similar values, with the ECMWF values being greater than the other two.

The wave-height values produced from the wave models AUT and WAM cycle 3 with the same UKMO wind input are compared with those of the altimeter ERS-1. Along the first track (Fig. 16) ERS-1 values are greater than both wave values, while AUT values are greater than WAM values. This is consistent with the analysis of the statistical results through the episodes, where in regions of low wave energy $\left(H_{s}\right.$ values of the order of $1 \mathrm{~m}$ ), the AUT model gives higher wave heights than the WAM model. At the second track (wave-height values of the order of $3 \mathrm{~m}$ ) all three sources have comparable values. In particular, the wave models' results are similar along the whole track (Fig. 17).

\section{Conclusions}

Available wind products and wave models were tested on a semi-enclosed basin with special geomorphology: the Aegean basin. 

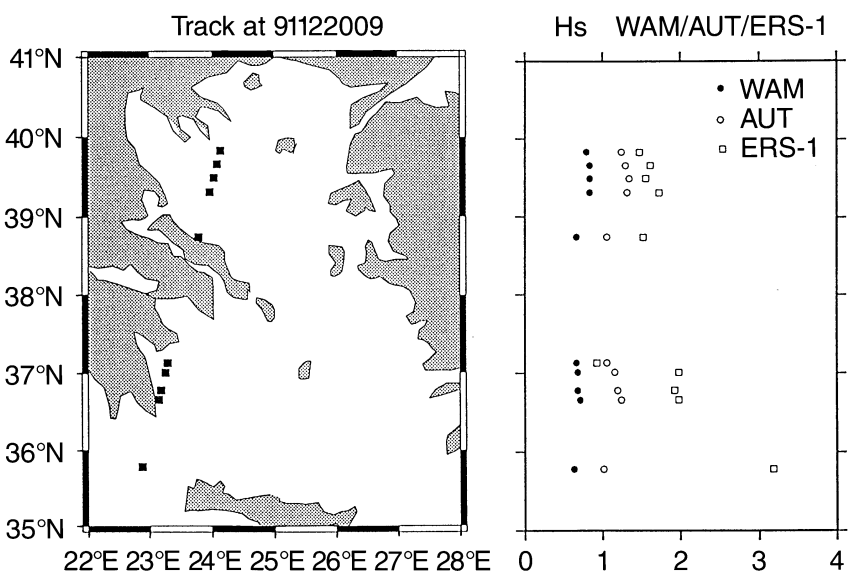

Fig. 16. Comparison of $H_{s}$ values between WAM, AUT models and ERS-1 wave data (track at 91122009)
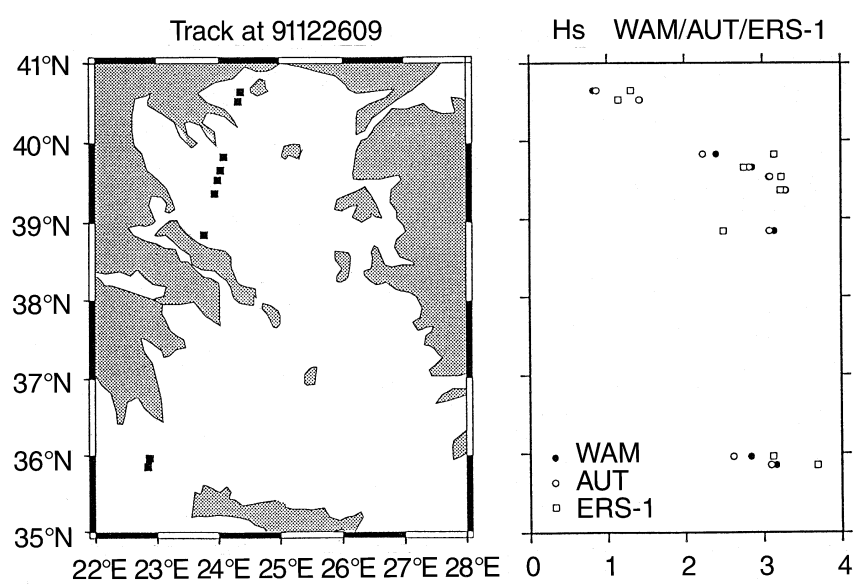

Fig. 17. Comparison of $H_{s}$ values between WAM, AUT models and ERS-1 wave data (track at 91122609)

The intercomparison study was based on checking the reliability of the wind input and the applicability of the various wave models. The selected cases covered different typical wind situations and the study was a synthetic analysis of wave-parameter time-series, statistical parameters for each storm case and a short-term comparison with satellite data. From the overall analysis the following points can be highlighted.

- The wind input is crucial for a basin with such a complicated topography and orography. Wind input must be provided on as fine a resolution grid as possible. Thus, till 1991, UKMO gave better results compared with the ECMWF wind source. After the doubling of both models in 1991 the wave results are improved, but still there is need to increase the windinput resolution to values lower then $40 \mathrm{~km}$, for the northern part of the basin. For the southern part it seems that the new resolution is adequate for both models.

- The various available wave models have different level of physics and applicability. Unidirectional wave storms from permanent winds, such as the Etesians during summer, can be hindcasted even with the simplest empirical models like the WACCAS (case 2). The second-generation wave model AUT gives similar results to the third-generation wave model WAM, although the latter is better in terms of physics and dynamics. This may be due to the small size and the geomorphology of the basin, factors that can balance the superiority of the WAM model itself, plus the fact that wind blows along the N-S axis of the basin for the majority of the cases (about $80 \%$ of the measured winds). This reflects the overall behaviour of the two models in the basin and not perhaps the characteristics of the waves in other special locations, such as the Saronicos Gulf (Athens) or some location within the area of Cyclades Islands, where the wavescatter across the numerous islands may affect significantly the wave estimation. Finally the computing time, which is much greater for WAM, has to be taken into account for the choice of model fulfilling the criteria for a specific application.

- The coarser resolution $\left(1 / 6^{\circ}\right)$ reproduces very well most of the islands: Sporades islands in the North Aegean, Cyclades islands in the South Aegean. The results are almost consistent with the $\left(1 / 12^{\circ}\right)$ grid test. Considering that the number of gridpoints adopted in the mesh of $\Delta x=\left(1 / 6^{\circ}\right)$ is $1 / 4$ of the grid points within the mesh of $\Delta x=\left(1 / 12^{\circ}\right)(894: 3583)$, we have chosen the $\left(1 / 6^{\circ}\right)$ as representative of the Aegean basin.

\section{Appendix}

Throughout the paper specific wave and statistical parameters were used that are defined here.

Wave parameters

Significant wave height:

$H_{s}=4 \sqrt{m_{0}}$

where $m_{0}$ is the total energy $m_{0}=\iint F(f, \theta) d f d \theta$.

Zero - crossing wave period:

$T_{z}=\sqrt{\frac{\int_{0}^{\infty} S(f) d f}{\int_{0}^{\infty} f^{2} S(f) d f}}$

Mean wave direction

$\theta_{m}=\arctan \left[\frac{\int_{0}^{2 \pi} \int_{0}^{\infty} \sin (\theta) F(f, \theta) d f d \theta}{\int_{0}^{2 \pi} \int_{0}^{\infty} \cos (\theta) F(f, \theta) d f d \theta}\right]$.

Statistical parameters

In the following formulas, $x_{i}$ stands for the reference (or first) timeseries of a model at the selected location, while $y_{i}$ stands for the corresponding values of the second model's time-series results. Mean value:

$\bar{x}=\frac{1}{N} \sum_{i=1}^{N} x_{i}$.

Bias:

Bias $=\frac{1}{N} \sum_{i=1}^{N}\left(y_{i}-x_{i}\right)=\bar{y}-\bar{x}$. 
Normalised bias:

$\epsilon_{\text {bias }}=\frac{1}{N} \sum_{i=1}^{N}\left(\frac{y_{i}-x_{i}}{x_{i}}\right)$.

Root mean square difference:

$r m s=\left[\frac{1}{N} \sum_{i=1}^{N}\left(y_{i}-x_{i}\right)^{2}\right]^{1 / 2}$.

Normalised rms difference or scatter index:

$\epsilon_{r m s}=\left[\frac{1}{N} \sum_{i=1}^{N}\left(\frac{y_{i}-x_{i}}{x_{i}}\right)^{2}\right]^{1 / 2}$.

Acknowledgements. This work was mainly supported by EC funds under contract MAST-0042-C(A). The author would like to thank Prof. C. Koutitas for his steady support and encouragement towards this line of research, Drs. L. Cavaleri and L. Bertotti, ISDGM, Venice, for fruitful and constructive discussions in experiencing the WAM world, and Dr. Jean Michelle Lefevre, Meteo France, for providing the ERS-1 satellite data. Also the Hellenic Meteorological Service (HMS) is acknowledged for providing wind data and their computer time in ECMWF to run the WAM implementation in Aegean Sea. Finally P. Wessel and W.H.F. Smith are acknowledged for their public domain G.M.T. software package, by means of which Figs. 17-20 were produced.

Topical Editor L. Eymard thanks H. Roquet and another referee for their help in evaluating this paper.

\section{References}

Athanassoulis, G. A., and E. Skarsoulis, Wind and wave atlas of the North-eastern Mediterranean Sea, NTUA Report, Athens, 1992.

Burgers, G., A guide to the Nedwam wave model, Scientific Report WR-90-04, KNMI, Koninklijk Nederlands Meteorologisch Institut, De Bilt, 1990.

Burrows, R., and D. K. Anastassopoulos, A wind wave hindcasting model based on the Jonswap relationships, Proc. Envirosoft '88, Porto Carras, Chalkidiki, Greece, 1988.

Carapiperis, L. N., The winds of the Greek Seas, Pub. Meteorol. Ins. Athens Univ., 8 (in Greek), 1968.

Catsoulis, V.D., Anemological conditions in the Aegean Sea, Ph. D. Thesis, University of Athens (in Greek), 1970.

Cavaleri, L., L. Bertotti, and P. Lionello, Wind wave cast in the Mediterranean Sea, J. Geophys. Res., 96 (C6), 10739-10764, 1991.
Cavaleri, L., L. Bertotti, C. Koutitas, S. Christopoulos, G. Komen, G. Burgers, K. Mastenbroek, J. M. Lefevre, A. Guillaume, J. C. Carretero, A. Guerra, L. Iovenitti, and P. Cherubini, An operational wave model for the Mediterranean Sea for hindcast and forecast applications - organization of a data base for regional modelling, MAST 0042 Final Scientific Report, 1993.

Christopoulos, S., Growth of wind waves - Analysis of measurements and predictive mathematical models, Ph. D. Thesis, Aristole University of Thessaloniki, 1989.

Christopoulos, S., and C. Koutitas, Wave modelling in the North Aegean Sea, Ann. Geophysicae, 9, 91-101, 1991.

Clancy, R. M., J. E. Kaitala, and L. F. Zambresky, The Fleet Numerical Oceanography Center Global Spectral Ocean Wave Model, Bull. Am. Meteorol. Soc., 67(5), 498-512, 1986.

Cullen, M. J. P., The unified forecast climate model, Scientific Paper No. 1, U.K. Meteorological Office, 1991.

Hasselmann, K., T. P. Barnett, E. Bouws, H. Carlson, D. E. Cartwright, K. Enke, J. A. Ewing, H. Gienapp, D. E. Hasselmann, P. Kruseman, A. Meerburg, P. Muller, D. J. Oibers, K. Richter, W. Sell, H. Walden, Measurements of windwave growth and swell decay during the Joint North Sea Wave Project (JONSWAP), Dtsch. Hydro. Z., Reihe A(12), 1973.

Hasselmann, S., and K. Hasselmann, Computations and parametrizations of the Nonlinear energy transfer in a Gravity-Wave spectrum. Part I: A new method for efficient computations of the Exact Nonlinear Transfer Integral, J. Phys. Oceanogr., 15, 1369-1377, 1985.

Janssen, P. A. E. M., Wave-induced stress and the drag of air flow over sea waves, Phys. Oceanogr., 19, 745-754, 1989.

Kassimidis, G., Numerical prediction of wave spectra over the Mediterranean Sea, Report No. 14, Hellenic National Meteorological Service, 1986.

Komen, G. J., S. Hasselmann, and K. Hasselmann, On the existence of a fully developed wind-sea spectrum, J. Phys. Oceanogr., 14, 1271-1285, 1984.

Komen, G. J., L. Cavaleri, M. Donelan, K. Hasselmann, S. Hasselmann and P. A. E. M. Janssen, Dynamics and Modelling of Ocean Waves, Cambridge University Press, Cambridge, 1994.

Laskaratos, A., Hydrology of the Aegean Sea, in Winds and currents of the Mediterranean basin, Ed. H. Charnock, Harvard reports in Oceanography and Meteorology, No. 40, 1992.

Simmons, A., Development of the operational 31-level T213 version of the ECMWF forecast model, ECMWF Newsletter, No. 56, 3-13, 1991

Snyder, R. L., F. W. Dobson, J. A. Elliott, and R. B. Long, Array measurements of atmospheric pressure fluctuations above surface gravity-waves, J. Fluid Mech., 102, 1-59, 1981.

WAMDI-Group, The WAM model - A third-generation ocean wave prediction model, J. Phys. Oceanogr., 18(12), 1775-1810, 1988. 